\title{
Review \\ Modification Methods of Diamond like Carbon Coating and the Performance in Machining Applications: A Review
}

\author{
Lijun Wang, Yan Liu *, Hui Chen * and Mengchao Wang
}

check for updates

Citation: Wang, L.; Liu, Y.; Chen, H.; Wang, M. Modification Methods of Diamond like Carbon Coating and the Performance in Machining Applications: A Review. Coatings 2022, 12, 224. https://doi.org/ 10.3390 / coatings12020224

Academic Editors: Vitaly Tseluikin and Lin Zhang

Received: 3 January 2022

Accepted: 28 January 2022

Published: 9 February 2022

Publisher's Note: MDPI stays neutral with regard to jurisdictional claims in published maps and institutional affiliations.

Copyright: (C) 2022 by the authors. Licensee MDPI, Basel, Switzerland. This article is an open access article distributed under the terms and conditions of the Creative Commons Attribution (CC BY) license (https:// creativecommons.org/licenses/by/ $4.0 /)$
Key Laboratory of Advanced Technology of Materials (Ministry of Education), School of Materials Science and Engineering, Southwest Jiaotong University, Chengdu 610031, China; lijun-123458@163.com (L.W.); wangmengchao@my.swjtu.edu.cn (M.W.)

* Correspondence: liuyanzt@163.com (Y.L.); xnrpt@swjtu.edu.cn (H.C.); Tel.: +86-10-87600726 (Y.L.); +86-10-87600726 (H.C.)

\begin{abstract}
The ideal cutting-tool coating material is characterized by unique chemical and physical properties to achieve excellent cutting performance, a good thermal barrier effect, and a high-quality machined surface. Diamond-like carbon (DLC) coating, as a kind of cutting-tool coating material, has been used in cutting various materials due to its low coefficients of friction and thermal expansion, high hardness, and good chemical inert and thermal conductivity. This article mainly focuses on the modification methods for the DLC coating and their application in machining different materials. Firstly, the methods employed to improve the mechanical properties of DLC coating are reviewed and analyzed, including the multilayer structure design, transition layer, and doping other elements. Secondly, the machining performances of DLC-coated tools in the application of different materials are summarized. This review provides knowledge of modification mechanisms regarding DLC coating and its effects on mechanical properties. For machining different materials, it provides a reference to make a suitable selection and design of DLC coating to obtain better machining performance.
\end{abstract}

Keywords: diamond-like carbon (DLC)-coated tools; cutting performance; modification methods; wear mechanism

\section{Introduction}

\subsection{Cutting Process and Cutting-Tools Wear Mechanism}

As a metal processing technology, cutting involves three main procedures of local plastic deformation, fracture and chip removal to obtain a targeted geometry and shape, generating a large amount of stress, strain, and heat accumulation [1]. The cutting-tools' failures are presented in the form of a blunt cutting tip, flank wear, rake wear, and a built-up edge (BUE), as shown in Figure 1. A BUE involves the chip adhering to the cutting-edge under high force and heat, especially in machining lightweight alloys. The fatigue fracture occurs at BUE and forms abrasive particles because of cyclical stress under the contact with the workpiece, which accelerates cutting-tool wear, destroying the cutting-edge profile and deteriorating the surface finish quality of the workpiece, affecting the dimensional precision of the machined part [1]. The surface quality and dimensional precision of the workpiece are crucial evaluation indicators for the cutting process, which is correlated not only with BUE formation but also with the tool edge radius. A large tool edge radius causes ploughing deformation rather than chip formation, which in turn increases tool wear and does not completely cut off chips, and the chips pile up on the surface of the machined material, leading to burr formation [2,3]. Burr formation depends not only on the sharpness of the cutting tool but also on the tool coating, which can provide a high-quality surface by improving the wear resistance of the tool. Therefore, BUE reduction contributes to sustaining the sharpness of the cutting-tool's edge, decreasing cutting force and enhancing the machinability of hard-to-machine materials. 


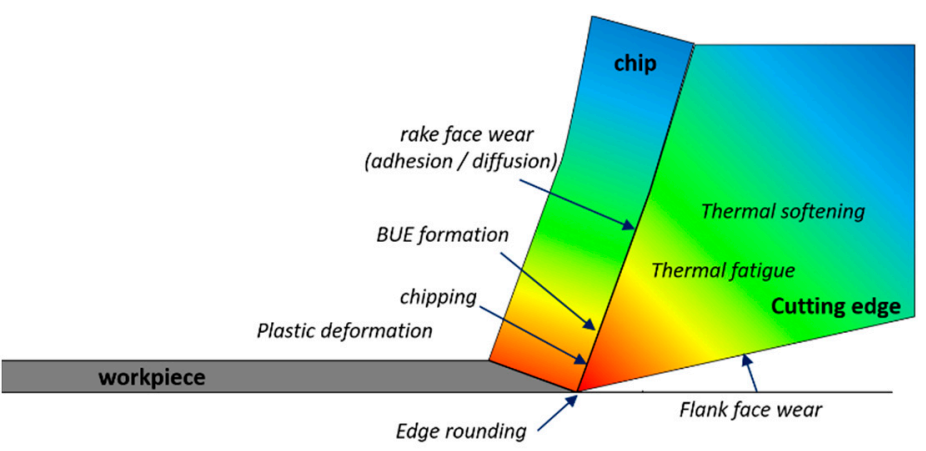

Figure 1. Schematic illustration of cutting-tool failures.

Generally, the failure of cutting tools develops in three stages, namely the running-in stage, stable-state stage and catastrophic damage stage. Cutting tools wear quickly at the initial stage because of the high stress induced by the rough surface of the tools. The material removed from the specimen mainly occur at the second stage, where the cutting tools are used with little wear damage. Elevated cutting force and heating accumulation cause excessive tool-edge wear at the third stage. A. Suárez et al. [4] investigated the tool wear patterns on turning inserts used on alloy IN718.

Tool wear occurs under a comprehensive effect that involves mechanical, thermal and chemical effects. The wear mechanisms include abrasive, adhesion, diffusion and oxidation wear, the reasons, results and solutions of which are illustrated in Figure 2.

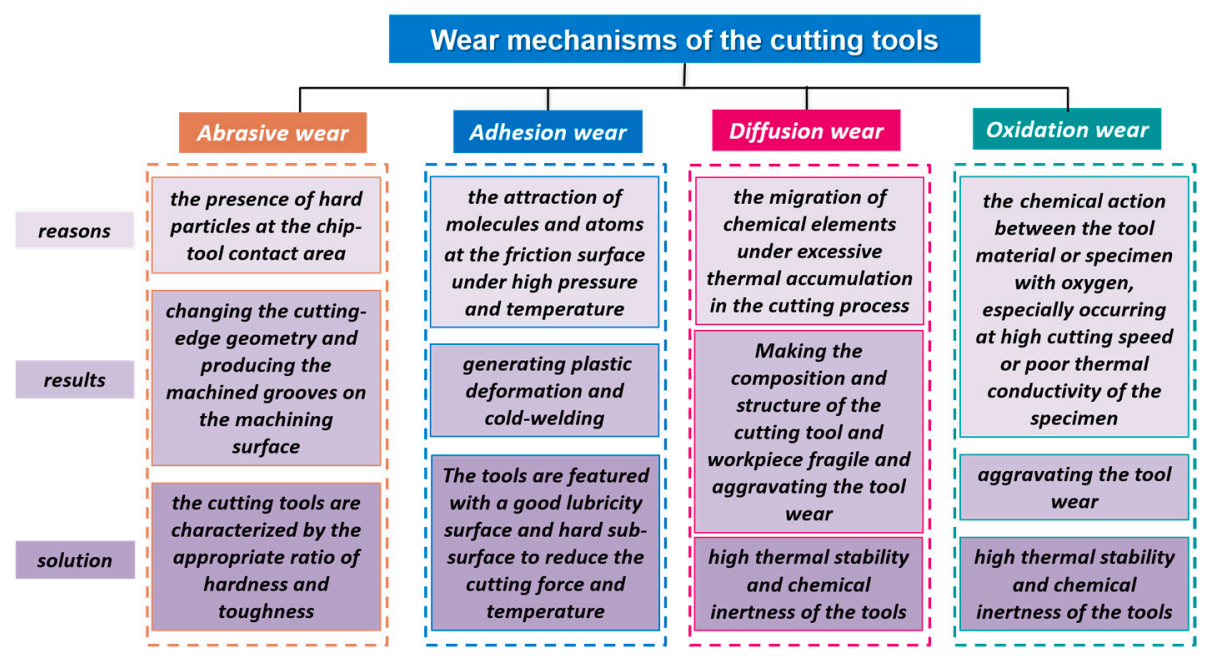

Figure 2. Wear mechanisms of the cutting tools.

Thus, cutting tools with a combination of high hardness, excellent wear resistance, superior chemical inertness and superb thermal stability provide a desirable machining performance and a high surface quality of machined materials.

\subsection{Cutting Tools with Coatings}

Cutting-tool materials are classified into three types, consisting of high-speed steel, cemented carbide, and super-hard materials. Powder metallurgy high-speed steel is a novel steel with high strength and toughness, which can be used as a cutting tool with a long service life. Cemented carbide is dominant among tool materials due to its competitive cutting performance in high-speed cutting and dry cutting. With the help of doping with rare earth elements, nanotechnology, and ultra-hard coating technology, cemented carbide is extensively used in the machining field. Super-hard materials mainly include ceramics, polycrystalline cubic boron nitride (PCBN) and polycrystalline cubic diamond (PCD) [5], 
with ultra-high hardness and anti-wear properties, significantly increasing the cutting efficiency, especially in difficult-to-machine materials.

Because of a combination of high hardness, superior wear resistance, anti-oxidation and chemical stability together with a low friction coefficient, a coating material with a compound structure deposited on cemented carbide can protect the substrate against mechanical damage and thermal heat, alleviate friction between the tool and the chips, and ensure valid and stable cutting under high cutting temperatures [6,7]. As demonstrated by Jamari J et al. [8], a lower coefficient of friction enhances the wear performance.

There are a great number of studies [9-13] examining wear and cutting mechanisms and the design of coating materials to increase the durability and cutting efficiency. In the literature, coatings with high wear resistance, including TiAlN, AlCrN, and diamond, diamond-like carbon (DLC) coatings, exhibited excellent cutting performance. S.N. Grigoriev et al. [9] adopted the PECVD technology to deposit nano-multilayer DLC-Si/DLC onto cemented carbide to obtain high thermal stability. The nano-multilayer DLC-Si/DLC cutting tool exhibited a longer lifetime than the single-layer DLC cutting tool. L. Huang et al. [10] fabricated a Ti-DLC / $\alpha-\mathrm{C}: \mathrm{H}$ multilayer-coated cutting tool with high adhesion and toughness to highly improve the cutting performance. Ch Sateesh Kumar et al. [11] reported that the cutting tool with a DLC coating provides better anti-adhesive performance in the dry turning of hardened 52,100 steel owing to the low-friction coating. A.I. Fernández-Abia et al. [12] evaluated the performance of four PVD-coated tools for turning austenitic stainless steels and analyzed cutting forces and flank wear evolution. RodríguezBarrero S. [13] investigated the cutting performance of nanostructured coatings in droplet elimination, maintaining a greater hardness at a higher temperature. A. J. Sánchez Egea et al. [13] analyzed the cutting performance of diamond blades in dry-cutting concrete.

The cutting forces [14] and heat accumulation developed during materials' machining operation are extremely critical in determining the surface quality of the machined workpiece and the performance and durability of the cutting tools $[15,16]$. As is known, the cutting forces reduce with an increase in cutting speed or a reduction in feed rate, and the temperature increases with an increase in both cutting speed and feed rate [17]. Luis Norberto López de Lacalle et al. [18,19] reported the relationship between cutting force and surface quality and analyzed the surface roughness in machining the brittle and ductile materials [20].

Employing coolants is a common method used to reduce the cutting forces and temperature in most cutting process [21]. However, the coolants generated adverse impacts on the manufacturing cost and the environment [22-24]. Therefore, the development of dry cutting applications has attracted more attention and has been promoted, which requires a novel cutting tool with a low coefficient of friction $(\mathrm{CoF})$ and superior anti-wear properties to reduce the machining force and temperature. DLC coatings are considered suitable candidates for dry machining.

\subsection{Diamond like Carbon (DLC)}

DLC films originally entered the machining field as a cutting-tool coating material in the 1990s, satisfying the modern manufacturing requirements of superior hardness and toughness, excellent wear resistance and a low $\mathrm{CoF}$, which contributed to enhancing the adaptability and durability of cutting tools $[25,26]$. DLC features a metastable amorphous structure, which is a spatial grid formed by a sp ${ }^{3}$ hybrid bond of the diamond phase and a $\mathrm{sp}^{2}$ hybrid bond of graphite cluster phase [27], the ratio of which varies within a wide range. Therefore, DLC has the characteristics of both diamond and graphite, with a combination of chemical inertness, high hardness (ranging from 30 to $50 \mathrm{GPa}$ ), low friction coefficients (0.1), good anti-adherence and high wear resistance [28]. DLC coating is used in various fields of industry, including cutting tools, machinery components, computer equipment, biomedical products, etc.

The mechanical performance of DLC films relies on the proportion of $\mathrm{sp}^{3}$ bonds, which is strongly associated with the ions' energy in the deposition process and with the 
deposition method [29]. DLC films can be fabricated by means of a variety of deposition techniques [29]. The common magnetron sputtering methods are characteristic of rather low ionization, causing poor mechanical properties on account of the chemical state of the DLC films with a high proportion of $\mathrm{sp}^{2}$ bonds. However, a high $\mathrm{sp}^{3}$ proportion can be obtained by means of tetrahedral amorphous carbon (ta-C) deposited using a cathodic vacuum arc generating plasma with a high fraction of highly charged ions, improving the mechanical properties. The ideal ion energy $(100 \mathrm{eV})$ for the highest $\mathrm{sp}^{3}$ proportion can be obtained by adjusting the negative bias to the substrate. Plasma-enhanced chemical vapor deposition (PECVD) is employed to prepare the hydrogenated amorphous DLC (a-C:H) films containing a large amount of hydrogen.

\subsection{Review Objective}

A DLC-coated tool with a low friction coefficient and good anti-adhesive properties has a reduced cutting temperature and cutting forces, which can improve the cutting performance. The critical problem of DLC coatings deposited on cutting tools is the high internal compressive stress and poor adhesion strength to limit the cutting performance [30]. The failure modes of DLC coatings and causes were shown in Figure 3. Many different methods can be used to solve this limitation and to synthesize thicker DLC coatings. Knowledge of the impact of DLC coating modification on mechanical and cutting performances is an important issue for machining different workpieces. Several studies have undertaken such research, but systematic and detailed reviews referring to the cutting performance of DLC coatings are still lacking. The discussion of various means to develop the mechanical properties of DLC coatings, and the cutting performance of modified DLC coatings are reviewed and analyzed in this study.

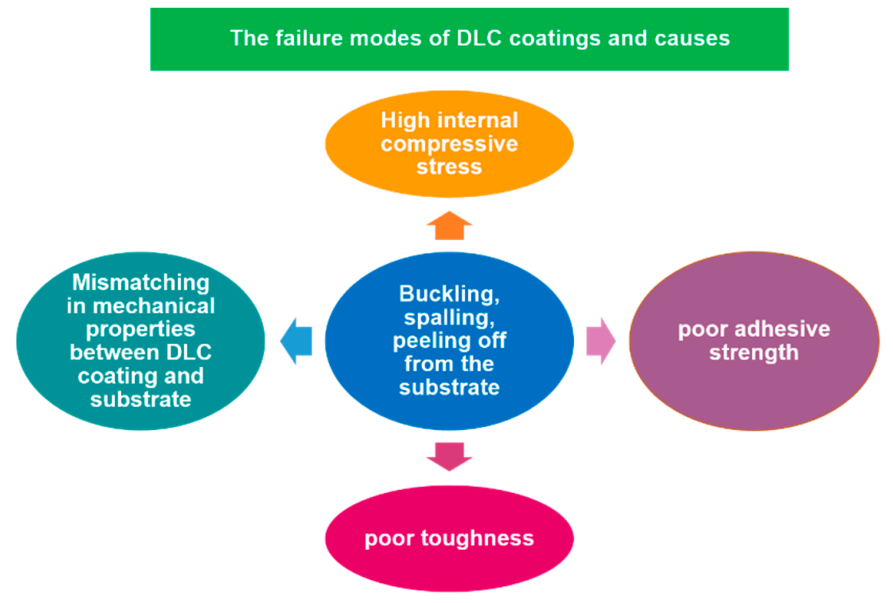

Figure 3. The failure modes of DLC coatings and causes.

\section{Methods to Improve Mechanical Properties for DLC Films}

Despite various merits characterized by DLC films, there are some limitations to their performance. Both the high residual compressive stress from the complicated cross-linked $\mathrm{sp}^{3}$ bonds and thermal stress from the mismatches of the elastic modulus and expansion coefficient between the DLC film and the substrate give rise to weak adhesion to the substrate and poor toughness. Especially under harsh cutting conditions with high cyclic fatigue, DLC films with a high compressive stress tend to fracture or even flake off in the initial phase, which significantly restricts their cutting application [31-33]. A great many studies aimed to increase the toughness, adhesion strength and tribological characteristics of DLCcoated cutting tools using various methods. These studies adjusted the ratio of $\mathrm{sp}^{3} / \mathrm{sp}^{2}$ hybridization bonds by changing deposition parameters and designing the film material composition or structure, such as an alternated multilayer architecture design, doping with metal elements and interlayer deposition. Figure 4 shows the systematic diagram of modification methods of DLC coatings and the limitations that need to be resolved. 


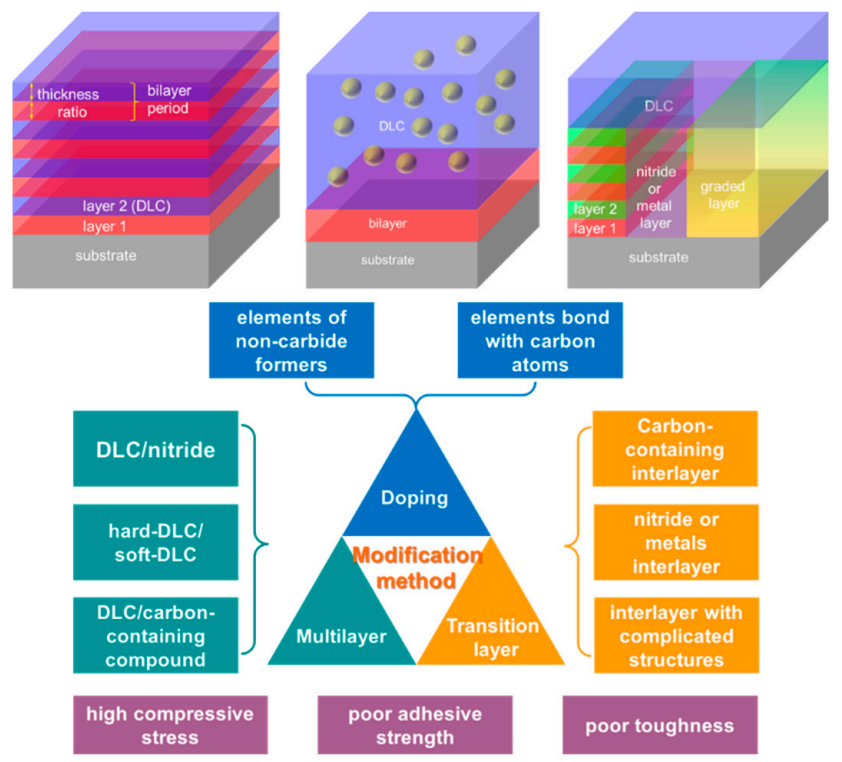

Figure 4. Systematic diagram of modification methods of DLC coating and limitations that need to be resolved.

\subsection{Multilayer System}

Based on the plastic deformation mechanism of the multilayer architecture, the multiple interfaces restrict the dislocation and defects in crystalline lattices and free volumes in amorphous structures, which contributes to improving the hardness and toughness. In addition, the defect being pinned by multi-interface structures helps to prevent crack formation and propagation under complicated stress field, where the multilayer interfaces act as barriers to stopping defect coalescence [34,35]. The schematic illustration of the stopping cracks mechanism of the multilayer design is shown in Figure $5 \mathrm{~d}$. Numerous studies have reported that the multilayer structure design for DLC films provides an increase in hardness and toughness and a decrease in internal stress, and further increases the tribological properties.
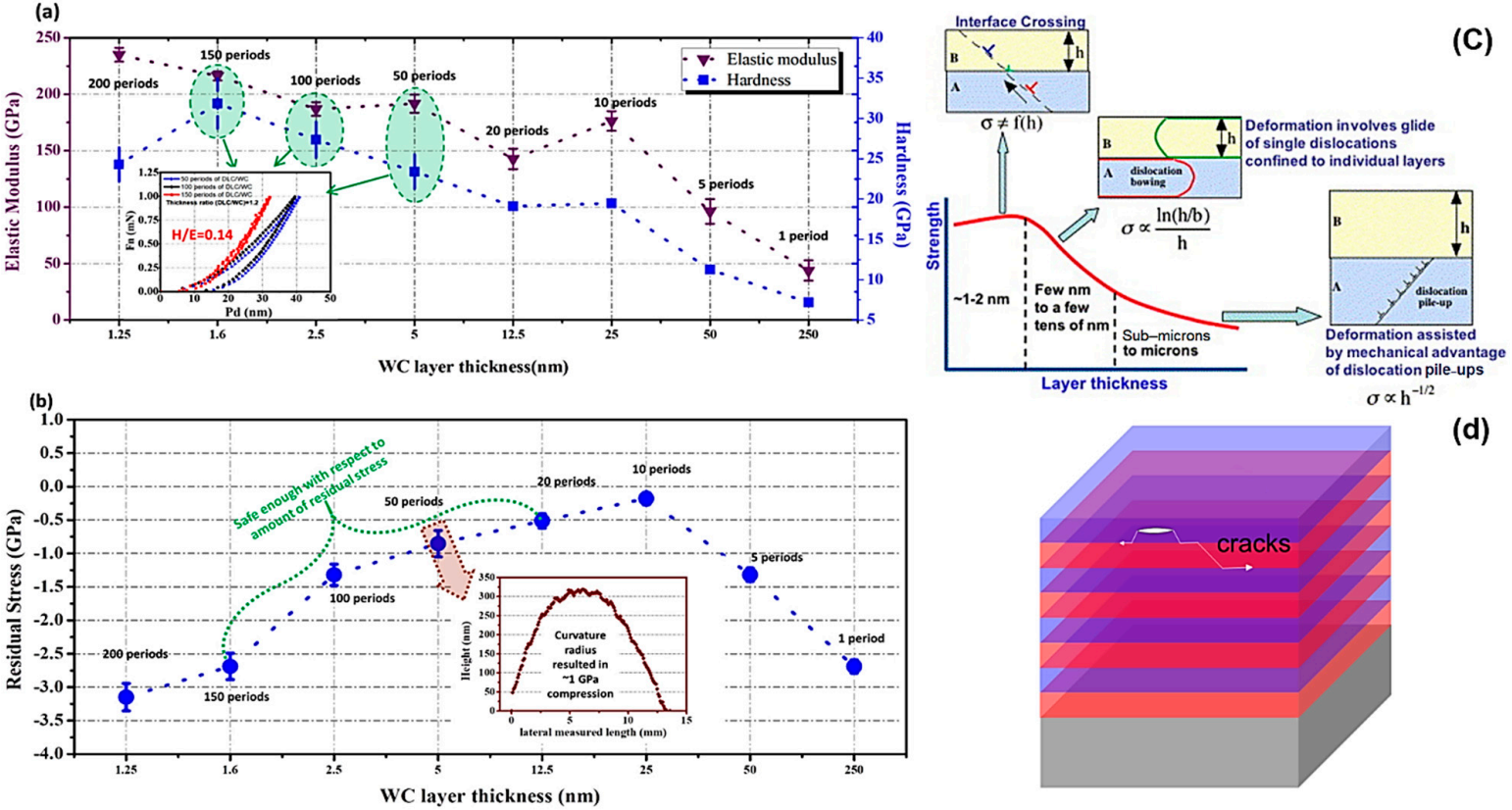

(d)

Figure 5. The effects of a bilayer period on the mechanical properties. (a) Elastic modulus and hardness, and (b) residual stress of WC/DLC coatings for the bilayer period [34]. (c) Schematic illustration 
of the dislocation mechanism of the multilayer strength operative at different length scales [35]. (d) Schematic illustration of the stopping cracks mechanism of the multilayer design.

Some studies referred to multilayer films composed of DLC and nitride alternant layers, such as TiN/a-C:H [36] and TiAlN/DLC [37]. The incorporation of carbon layers makes the biggest contribution to improving tribological properties. In addition, when the number of nitride layers increased, the hardness, CoF and wear resistance increased, but the fracture toughness decreased. The mechanical and tribological performances of the novel TiN/a-C:H multilayer coatings strongly depend on the bilayer period and thickness ratio [36]. Among them, the TiN/a-C:H coating with a $125 \mathrm{~nm}$ bilayer period and a 1:1 or 1:2 thickness ratio exhibited the optimal properties in hardness, fracture toughness and adhesion with the substrate, which showed better wear resistance. The TiAlN/DLC multilayer film [37] obtained at the bias of $-150 \mathrm{~V}$ with a $\mathrm{Cr} / \mathrm{CrC} \times / \mathrm{CrC}$ transition layer exhibited excellent adhesion $\left(\mathrm{L}_{C}=63 \mathrm{~N}\right)$ with the substrate, which is related to the surface morphology. The smooth surface obtained at a high bias is conducive to ion migration and diffusion to improve the adhesion. The thick TiAlN/DLC multilayer coating $(4.5 \mu \mathrm{m})$ without any interfacial failure was fabricated by adopting the gradually increasing biases and suitable composition.

There are some studies concerned with the multilayer films composed of alternating layers of DLC and $\mathrm{WS}_{2}$, named DLC/WS . The multilayered DLC/WS 2 coatings [1] deposited on the milling inserts were characterized by a coefficient of friction of 0.05 and high hardness, which are ascribed to the formation of a low CoF lubricant layer of WS and the increase in the interface adhesion strength, respectively. The $\mathrm{WS}_{\mathrm{X}} / \mathrm{a}-\mathrm{C}$ multilayer films [38] with an optimum thickness ratio exhibited an increased hardness, decreased adhesion and better tribological performances compared with a single $\mathrm{WS}_{X}$ film.

In some studies, the multilayer films composed of alternating layers of DLC and carbon-containing compound, such as Ti-DLC/a-C:H [10] and WC/DLC [34], were considered as candidates to further improve the hardness and adhesion. The Ti-DLC/a-C:H multilayer film displayed a lower fraction of $\mathrm{sp}^{3}$ bonds and a higher content of $\mathrm{sp}^{2}$ bonds compared to the monolayer a-C:H film, which verified that the compressive stress of the DLC film can be effectively released by an alternating multilayer construction. In addition, the Ti-DLC/a-C:H multilayer film showed superb adhesion to the substrate, toughness and the lowest $\mathrm{CoF}$ and wear rate, superior to each monolayer film, implying an excellent wear performance. Narguess Nemati et al. [34] introduced a multilayered WC/DLC coating with the combination of super-high hardness ( $>45 \mathrm{GPa})$, high $\mathrm{H} / \mathrm{E}(\sim 0.15)$, low compressive residual stress $(<3 \mathrm{GPa})$, excellent creep deformation resistance and highly resistant wear behavior (wear rate $<10^{-13} \mathrm{~mm}^{3} / \mathrm{n} \mathrm{mm}$ ) by optimizing the period number and adopting low-temperature annealing, which is the highest state in the mechanical properties of the multilayer. The migration and diffusion of carbon from WC to the DLC layer after annealing at $250{ }^{\circ} \mathrm{C}$ resulted in a rise in the fraction of $\mathrm{sp}^{3}$ bonds. Hence, low-temperature annealing $\left(<400{ }^{\circ} \mathrm{C}\right)$ generated an increase in the mechanical properties of the coating through the thermally induced redistribution of carbon. Figure 5a,b illustrate that the hardness, elastic modulus and residual stress of the WC/DLC coating are significantly correlated with the bilayer periods. The dislocation mechanisms of metallic multilayers are illustrated in Figure 5c. The Hall-Petch model fits the data well in the layer thickness range of 5-100 nm, but overestimates the strength at lower thicknesses.

Some studies reported that the alternating hard DLC-layer and soft DLC-layer multilayer architecture was synthesized by adjusting the bias voltages. Jing Wei et al. [39] reported that tetrahedral amorphous carbon (ta-C) films with a multilayer construction

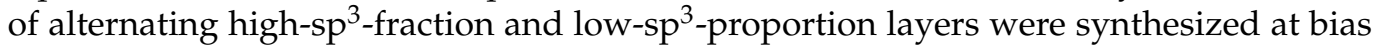
voltages alternating between $-150 \mathrm{~V}$ and $-50 \mathrm{~V}(\mathrm{M}-1)$ using the filtered cathodic vacuum arc (FCVA) technique. The wear rate and mechanical properties of the different multilayers are shown in Figure 6. Multilayer ta-C film with optimum period ratio showed lower residual stress $(6.2 \mathrm{GPa})$, a lower wear rate $\left(2.87 \times 10^{-7} \mathrm{~mm}^{3} / \mathrm{n} \mathrm{m}\right)$ and a lower coefficient 
of friction (0.06) than that of the single ta-C film. In addition, the multilayer architecture effectively restricted spalling and peeling of ta-C film. Yanyan Lin et al. [40] reported that a DLC multilayer coating comprising alternating hard layers and soft layers was fabricated by using an unbalanced magnetron sputtering system. The wear rate of DLC coatings with different bilayer periods and thickness ratios, and the SEM morphologies of the worn wear tracks at an applied load of $80 \mathrm{~N}$, are illustrated in Figure 7. Among them, the $50 \%$ hard multilayer with a bilayer thickness of $61 \mathrm{~nm}$ displays better toughness and anti-abrasive properties than the monolayer hard DLC coating, especially at a contact load of $3.65 \mathrm{GPa}$. Under the high load, toughness is crucial to influence the wear resistance, while under the low load, the wear rate is highly related to the hardness. The alternating incorporated low-sp ${ }^{3}$-fraction layers in the multilayer construction contribute to plastic deformation by alleviating the high compressive stress. In addition, the interfaces between the soft layer and the hard layer in the multilayer architecture provide barriers to restrict the initiation and propagation of cracks.
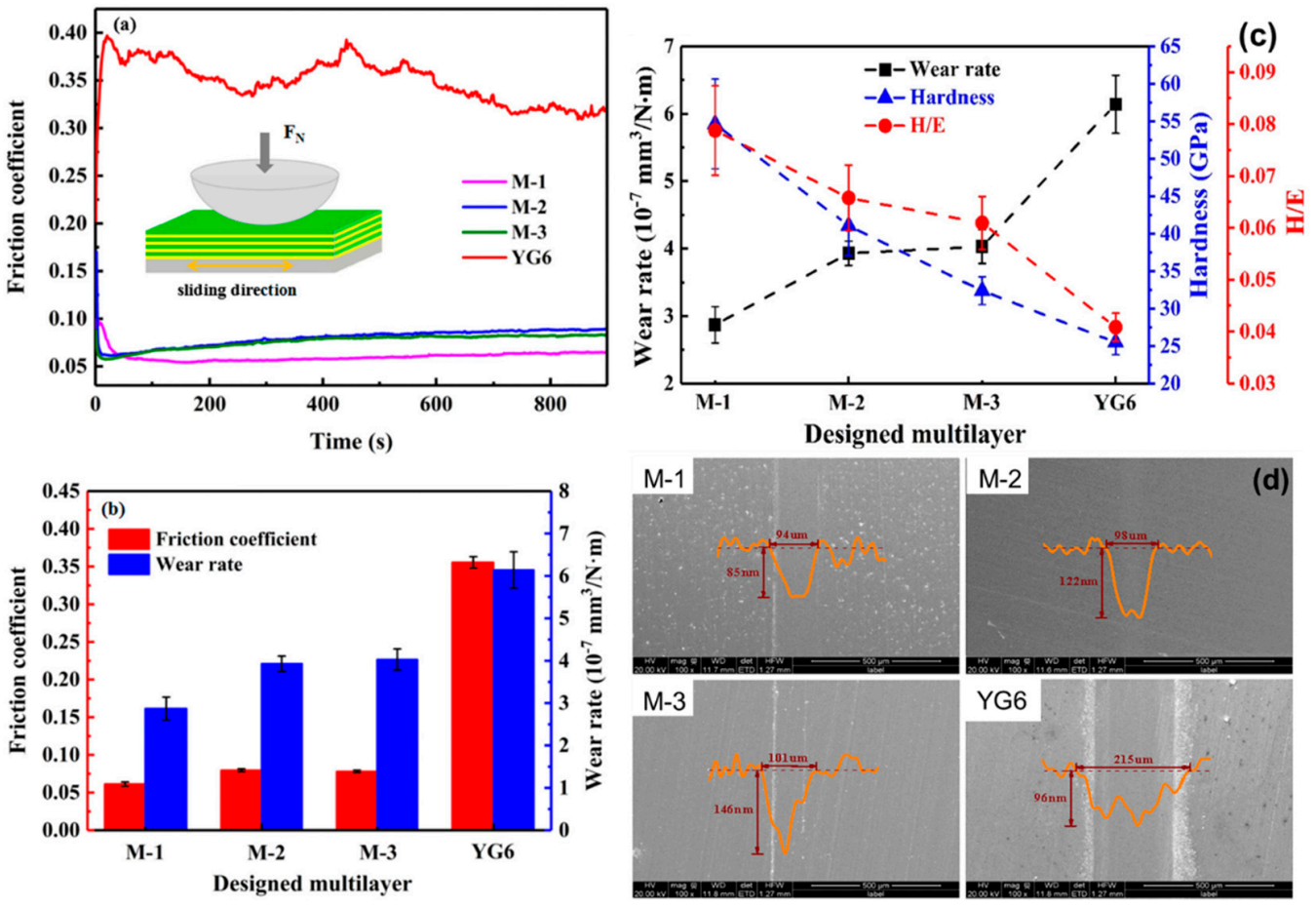

Figure 6. DLC multilayer construction of alternating high-sp ${ }^{3}$-fraction and low-sp ${ }^{3}$-proportion layers [39], M-1: 51/60 ( $\mathrm{sp}^{3}$ content ratio), M-2: 44:60, M-3: 36:60, YG6: substrate. (a) Friction coefficient curves against sliding times. (b) Average friction coefficient and wear rate of samples. (c) Wear rate, hardness and H/E ratio of the samples. (d) Surface and cross-sectional profiles of wear tracks.

Considering the effects of the multilayer structure design on the mechanical properties of the DLC coating, a few mechanisms can be obtained as follows:

(1) The multilayer structure design for DLC films provides an increase in hardness and toughness and a decrease in internal stress, and further increases the tribological properties, due to the multi-interface structures.

(2) The multilayer interfaces act as barriers to defect coalescence and prevent crack formation and propagation under a complicated stress field, which improves the toughness of the coating.

(3) Both the bilayer period and the thickness ratio are important parameters to control the performance of the multilayer DLC coating. 

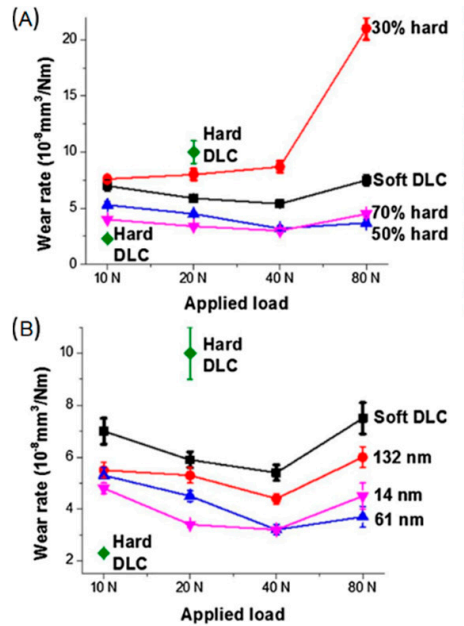

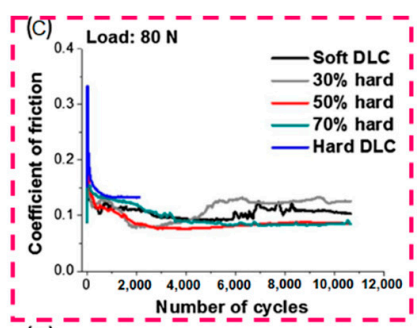

(D) -1 Lad: $80 \mathrm{~N}$

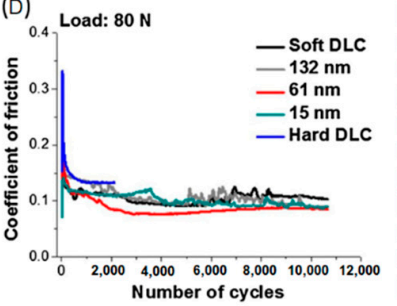

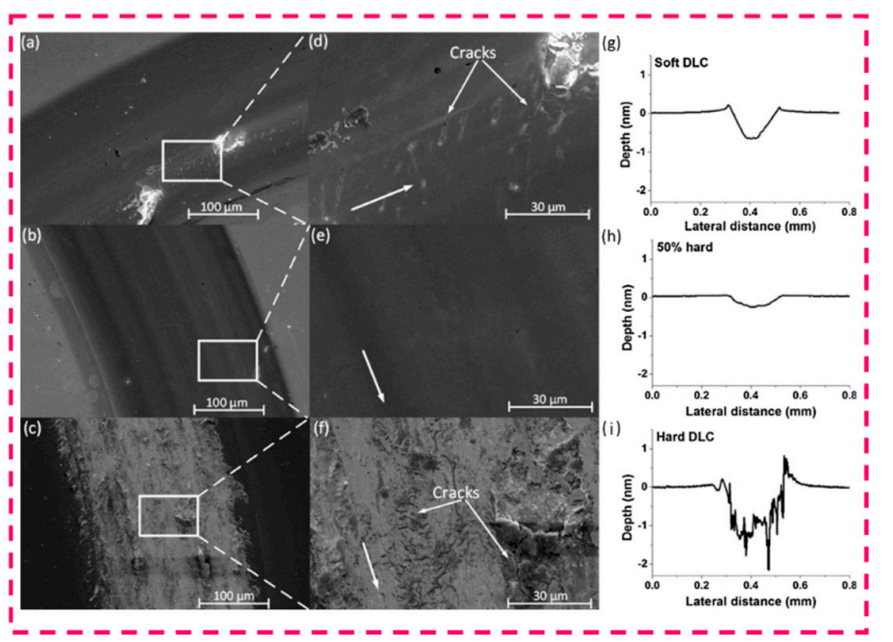

Figure 7. Wear rate of DLC coatings (A) with different percentages of hard-layer thickness and (B) with different bilayer thickness. Typical coefficient of friction curves of DLC coatings (C) with different percentages of hard-layer thickness and (D) with different bilayer thickness. and SEM morphologies of the worn wear tracks, applied load: $80 \mathrm{~N}$. (a) single layer soft DLC, (b) 50\% hard multilayer DLC, (c) single hard DLC. (d-f) are the magnified images of the corresponding white rectangle area in $(\mathbf{a}-\mathbf{c})$ respectively. $(\mathrm{g}-\mathbf{i})$ are cross-sectional 2D profiles of the wear track [40].

\subsection{Transition Layer System}

A valid solution to relieve the high internal stress and increase the adhesive strength to the substrate in DLC coatings is a small gap in elastic modulus values between the coating and the substrate, which improves the wear resistance and durability of the DLC coatings. The introduction of graded transition layers between the DLC and the substrate can successfully address this issue, generating the redistribution of the internal stress and high adhesion to the substrate.

In several studies [41-43], introducing a carbon-containing intermediate layer increased the adhesion strength to the substrate of the DLC coating. The transitional layer of silicon ( $\mathrm{Si}$ )-doped diamond-like carbon (Si-DLC) significantly enhanced the adhesion strength between the DLC coating and the nitrile-butadiene rubber (NBR), showing excellent tribological performance and taking advantage of piston seals [42,43].

Some studies reported that the nitride layer acted as a transition layer to enhance the adhesion. The $(\mathrm{Cr}, \mathrm{Al}, \mathrm{Si}) \mathrm{N}$ layer, featuring high hardness (55 GPa), sufficient ductility and high thermal stability, was used as a transition layer between the $\left(\mathrm{Al}_{2} \mathrm{O}_{3}+\mathrm{TiC}\right)$ ceramic substrate (hardness of 15-20 GPa) and the DLC coating (hardness from 30 to $80 \mathrm{GPa}$ ) [9]. The $(\mathrm{Cr}, \mathrm{Al}, \mathrm{Si}) \mathrm{N}$ transition layer exhibited excellent adhesion strength and good plasticity, improving the wear resistance of the DLC coating. W. Henderer et al. [44] reported that the TiSiN-CrCx/a-C:H double layers coated on the cutting tools improved cutting performance in tapping aluminum-silicon alloys, owing to the TiSiN base layer with high hardness and the $\mathrm{CrC}_{\mathrm{X}}$ / a-C:H top layer with low CoF. According to Javier Fernández Landeta [45], lower force and torque values resulted in lower tap wear. Li-Chin Cheng et al. [46] proposed that the CrAlSiN/DLC double layers exhibited higher hardness and lower CoF than the single-layer CrAlSiN.

A few studies used metals as an interlayer connecting the substrate and the DLC coatings, and found that the formation and stabilization of $\mathrm{sp}^{2}$ cluster size mainly depend on the chemical nature of different metals [47-49]. Fatemeh Shahsavari et al. [50] applied $\mathrm{Ni}$ and $\mathrm{Cr}$ metallic interlayers to increase the adhesion between the silicon substrate and the DLC coating. The DLC coatings prepared on Cr layers were characterized by a much smoother morphology, as shown in Figure $8 \mathrm{a}, \mathrm{c}$, along with more $\mathrm{sp}^{3}$ bonding and much lower residual stress than those on Ni layers, which was ascribed to them forming stable carbides and applying more sites for the nucleation and growth of carbon atoms. Moreover, 
the $\mathrm{Cr}$ interlayer with a thickness of $40 \mathrm{~nm}$ not only improved the adhesion of the DLC films but also generated the lowest $\mathrm{CoF}$, better wear resistance and the highest hardness $(27 \mathrm{GPa})$, as shown in Figure 8. Both the chemical (atomic structure) and physical (thickness and surface roughness) properties of interlayers played a role in the final morphology, mechanical and tribological properties of DLC film.
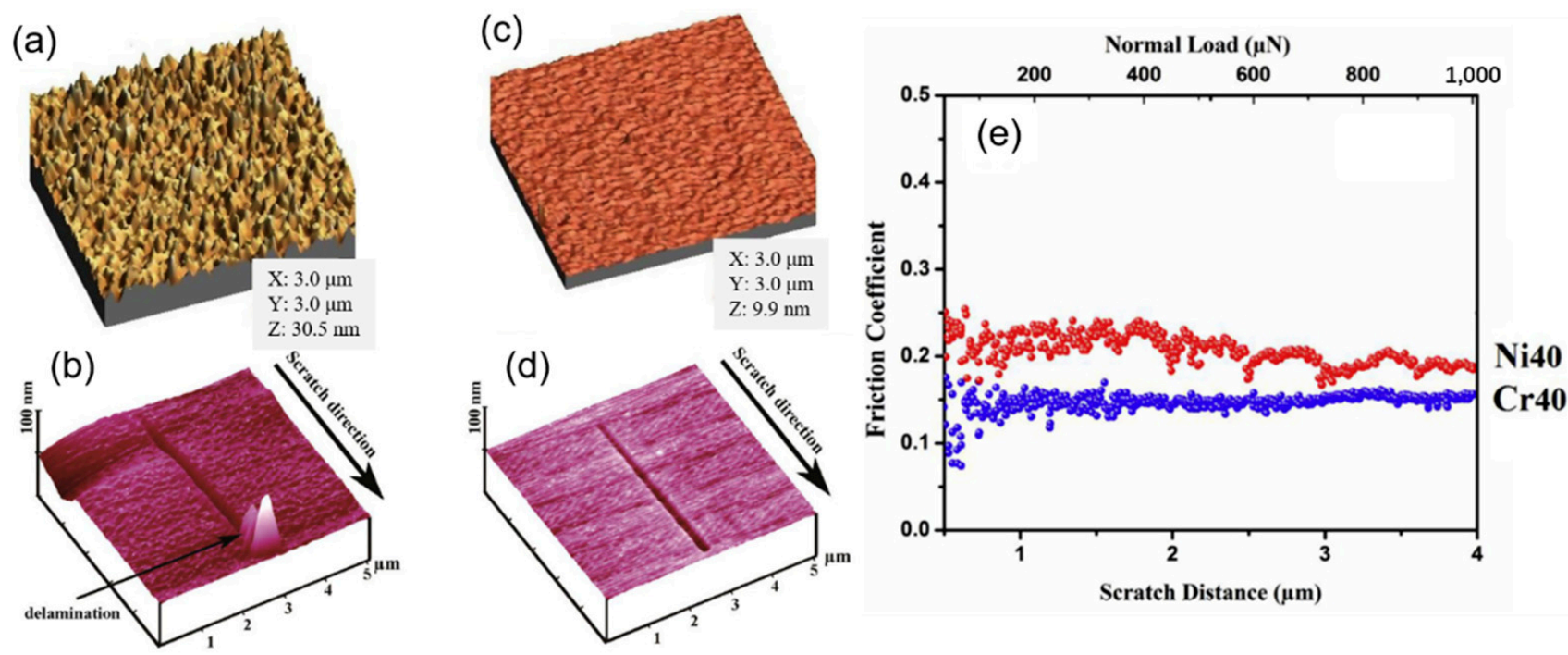

Figure 8. DLC coating with Ni and Cr metallic interlayers [50]. AFM images of the Ni nanolayer (a) and the Cr nanolayer (c); AFM images of nano scratch test of DLC on $\mathrm{Ni}(\mathbf{b})$ and $\mathrm{Cr}$ (d); (e) friction coefficient with increasing load.

Some studies referred to transition layers with complicated structures, such as multilayer and graded layer structures. Duminica et al. [51] studied four different transition layers with a multilayer design employed to enhance the adhesion to the substrate of stainless steel and global wear resistance, as illustrated in Figure 9. The DLC coating with a complex multilayer transition layer consisting of a $\mathrm{Cr}$ base layer, a $\mathrm{CrN}$ intermediate layer and a $\mathrm{Cr} / \mathrm{C}$ multilayer (Cr/CrN/Cr-DLC/DLC \#2) exhibits cohesive failures with buckling and spallation at the initial location of the scratch. The $\mathrm{Cr} / \mathrm{CrN} / \mathrm{CrN}-\mathrm{DLC} / \mathrm{DLC}$ (\#1) coating presents flaking and peeling at the edge of the indentation. On the other hand, the Cr/Cr-DLC/DLC (\#4) coating shows good adhesion strength with a few radial cracks, and has excellent mechanical and tribological properties. The incorporation of the CrN layer into the coatings (\#1 and \#2) gives rise to poor adhesion and more brittleness, with delamination and peeling located at the border of the contact point compared to the coating without the $\mathrm{CrN}$ layer. The DLC coating with a $\mathrm{Cr}$ base layer and a $\mathrm{Cr} / \mathrm{C}$ multilayer intermediate layer (Cr/Cr-DLC/DLC \#4) seems to be a good candidate with excellent mechanical properties and wear resistance. Xudong Sui et al. [52] developed the Cr-containing DLC coating with a transfer layer with a CrN/DLC multilayer architecture, which is characterized by hard Cr layers in combination with lubricant amorphous DLC layers, and presents better fracture toughness in the indentation process, in comparison with the single DLC and CrN coatings with large cracks and delaminated regions. Moreover, the presence of interfaces in the transfer multilayer structure is conducive to restraining crack propagation. The CrN/DLC/Cr-DLC coating exhibited a low wear rate, which is attributed to the DLC lubricant layer, hard $\mathrm{CrN}$ load-support layers and interfaces in crack inhibition. Figure 10 displays the indentation morphologies and 3D images and cross-sectional profiles of wear tracks sliding with an AISI 440C ball. 


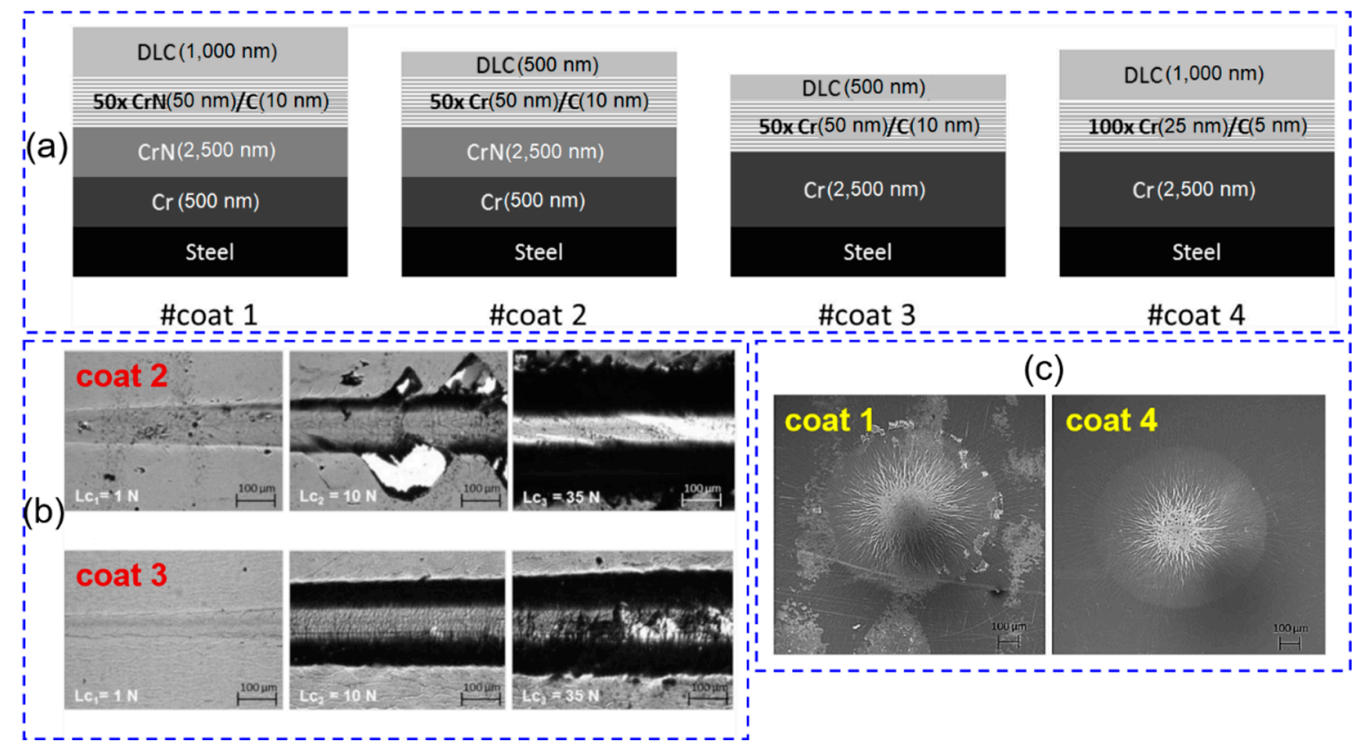

Figure 9. The adhesion evaluation of DLC coating with a complex multilayer transition layer [51]. (a) coating design for the various deposition conditions, (b) scratch track optical observation of sample \#coat 2 and sample \#coat 3, (c) SEM micrographs of the Rockwell test impacts of sample \#coat 1 and sample \#coat 4 .
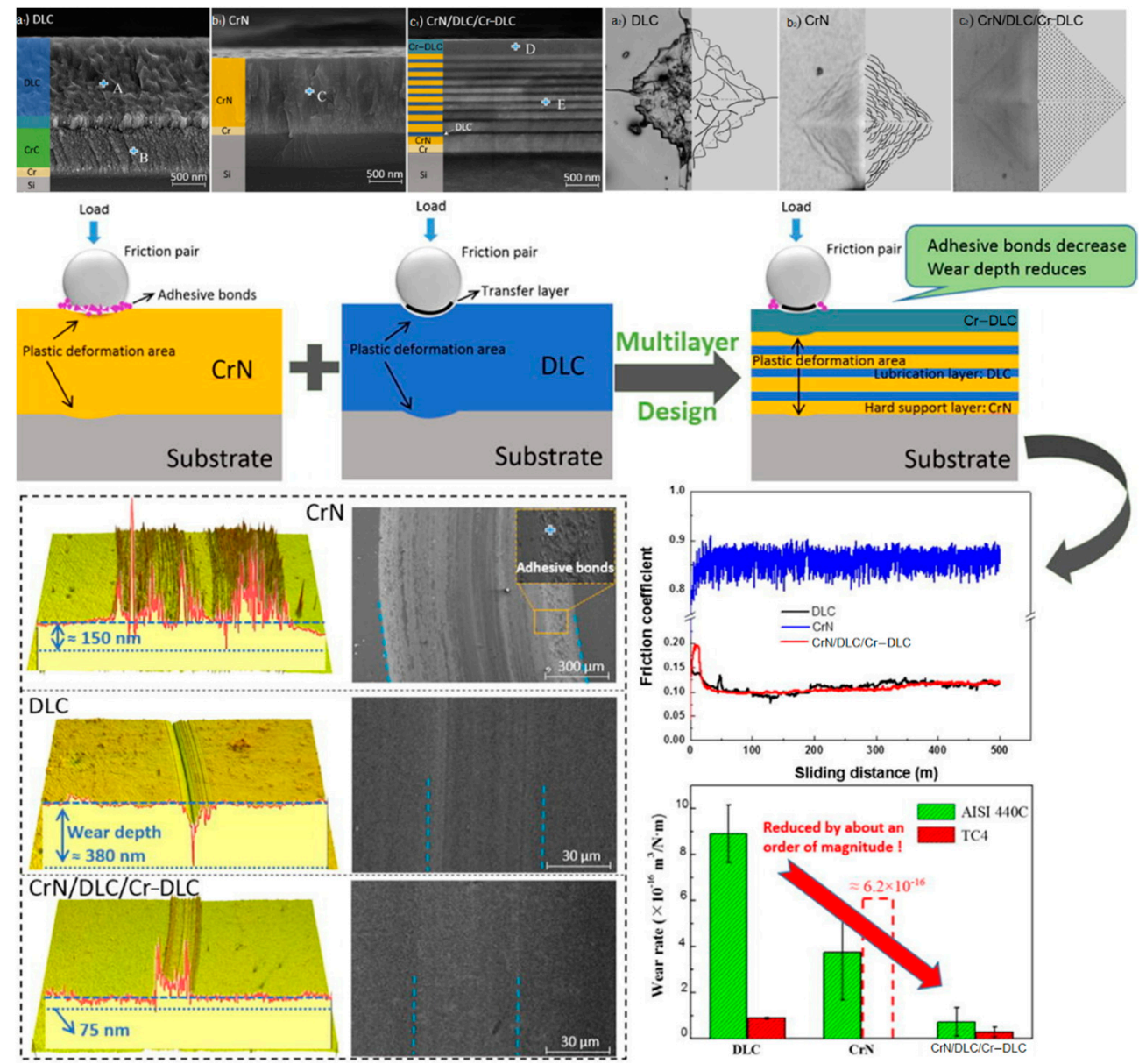

Figure 10. Cross-section SEM images of the coatings: $\left(\mathbf{a}_{\mathbf{1}}\right) \mathrm{DLC},\left(\mathbf{b}_{\mathbf{1}}\right) \mathrm{CrN},\left(\mathbf{c}_{\mathbf{1}}\right) \mathrm{CrN} / \mathrm{DLC} / \mathrm{Cr}-\mathrm{DLC}$; Indentation morphologies of $\left(\mathbf{a}_{2}\right)$ DLC, $\left(\mathbf{b}_{2}\right) \mathrm{CrN},\left(\mathbf{c}_{\mathbf{2}}\right) \mathrm{CrN} / \mathrm{DLC} / \mathrm{Cr}-\mathrm{DLC}$; and 3D images and crosssectional profiles of wear tracks sliding with an AISI 440C ball [52]. 
Based on the influence of the incorporation of the transition layer on the mechanical performance of the DLC coating, a few mechanisms can be obtained as follows:

(1) The elastic modulus and coefficient of thermal expansion of the transition layer located between the substrate and the DLC top layer significantly reduce the thermal stress at the interface and increase the adhesion strength.

(2) A lower surface roughness of the transfer layer results in the formation of a smooth DLC film with a lower friction coefficient, more stress reduction and better adhesion strength. The chemical structure of the interlayer was important in the solubility and diffusion of carbon atoms and consequently in the instability of $\mathrm{sp}^{3}$ and $\mathrm{sp}^{2}$ bonding.

(3) The intermediate layer with a multilayer architecture not only contributes to stress relief and adhesion increase, but also to crack propagation inhibition.

\subsection{Doping System}

Large number of studies reported on the addition of chemical elements ( $\mathrm{W}, \mathrm{Si}, \mathrm{Cr}$, $\mathrm{Mo}, \mathrm{Cr}, \mathrm{Ti}, \mathrm{Ag}, \mathrm{Au}, \mathrm{Al}$, etc.) into DLC films, which is a new method for internal stress reduction and adhesion improvement. Meanwhile, this can suppress the deformation and propagation of cracks to enhance the toughness.

Some researchers found that some specific metal elements incorporated into the DLC coating can strongly bond with carbon atoms to form nano-clusters, which generated a great effect on the mechanical and frictional properties of DLC coatings [53,54]. Yeong Ju Jo et al. [54] reported that Ti-doped DLC films were deposited by a hybrid system, and the surface roughness and $\mathrm{sp}^{2} / \mathrm{sp}^{3}$ ratio increased with the respect to the increase in the $\mathrm{Ti}$ content. The presence of $\mathrm{Ti}$ ranged from the amorphous-phase $\mathrm{Ti}$ carbide at less than 2.8 at.\% to the nanocrystalline $\mathrm{TiC}$ phase, exceeding 4.0 at.\%. The introduction of $\mathrm{Ti}$ improved the adhesion of DLC films, as shown in Figure 11. C.W. Zou et al. [55] studied that DLC coatings doping with different $\mathrm{Cr}$ contents $(3,4.8,7.2$, and 9.7 at.\%) were fabricated by using a hybrid system. The ratio of $\mathrm{sp}^{2} / \mathrm{sp}^{3}$ hybrid bonds rises monotonically with the $\mathrm{Cr}$ incorporation content, which causes a reduction in the elastic modulus and hardness. The same conclusion occurs in the CrN/DLC/Cr-DLC multilayer coating with a Cr-doped DLC top layer [52]. Meanwhile, the Cr-DLC coatings demonstrate a dramatic decrease in the residual stress. The low-Cr content-doped DLC coating presents high thermal stability and excellent wear resistance without failure in the $400^{\circ} \mathrm{C}$ tribological experiment. J.A. Santiago et al. [56] also found that Cr-doped DLC (Cr-DLC) films with incorporated Cr amounts varying from 3 to 20 at.\% were deposited by means of the co-deposition system with HiPIMS (Cr deposition) and DC-pulsed technology (C deposition). The low doping amount of $\mathrm{Cr}$ (up to 3 at.\%) can maintain the original carbon structure and the mechanical properties, due to highly energetic plasma discharges from low HiPIMS frequencies. $\mathrm{Cr}$ doped DLC exhibited decreased hardness, elastic modulus, internal stresses, friction and wear rate in comparison with the DLC coating. In addition, the low Cr-doped DLC (at.\%) coating shows good ductility and wear behavior during the sliding test, in particular at high temperatures. The experimental results of the Cr-doped DLC film are illustrated in Figure 12.

Ai-ying Wang et al. [57] studied W-incorporated DLC coatings (W-DLC) with W concentrations ranging from 0 up to 8.6 at.\% using the hybrid ion beam deposition technique, as shown in Figure 13. For the W-DLC coating with a low W concentration $(<2.8$ at. $\%)$, the $W_{1-x}$ phase is not detected due to $W$ atoms distributed in the amorphous carbon matrix. For the W-DLC coating with W concentration between 2.8 and 3.6 at.\%, the crystalline $\mathrm{WC}_{1-\mathrm{X}}$ nano-particles appeared in the matrix. The chemical bonding states in amorphous carbon were not changed by the introduction of $\mathrm{W}$ atoms, which results in the hardness and elastic modulus remaining at the original level. However, the bonding structure of the $\mathrm{W}$ atoms in different $\mathrm{W}$ concentrations causes a dramatic reduction in the internal compressive stress through different mechanisms. When $W$ content is below 2.8 at. $\%$, the stress reduces due to the distortion of bond angles without an increase in elastic energy. However, when $\mathrm{W}$ incorporation is up to 3.6 at.\%, the residual stress increases due to the 
formation of a $\mathrm{WC}_{1-\mathrm{x}}$ phase with a longer $\mathrm{W}-\mathrm{C}$ bond than the $\mathrm{C}-\mathrm{C}$ bond. When higher $\mathrm{W}$ concentrations vary from 3.6 to 8.6 at. $\%$, the presence of nano-crystallites $\mathrm{WC}_{1-\mathrm{x}}$ causes the residual compressive stress to decrease gradually.

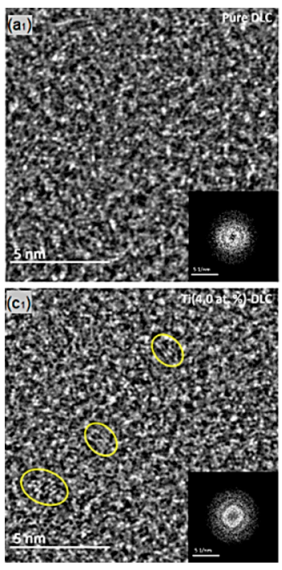

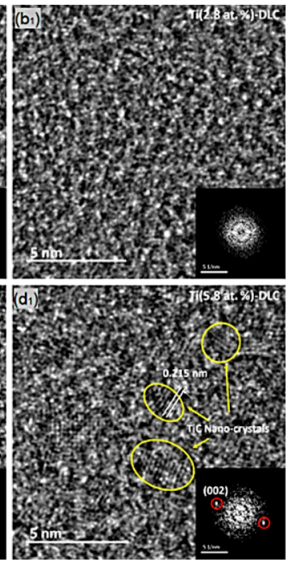
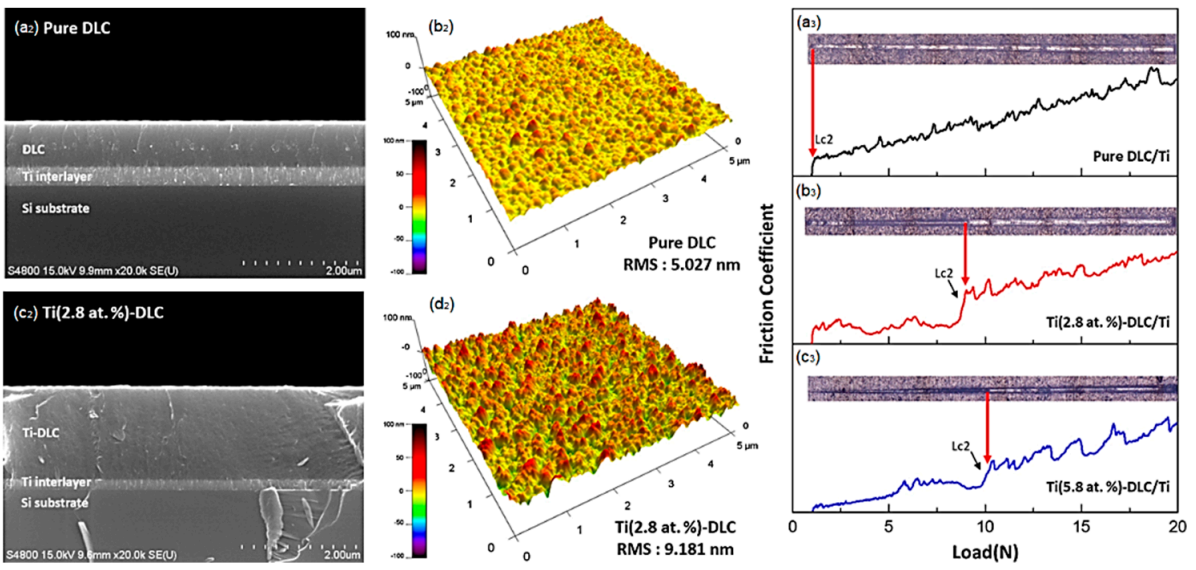

Figure 11. HR-TEM images with corresponding FFT images of $\left(\mathbf{a}_{1}\right)$ pure DLC film and Ti-DLC

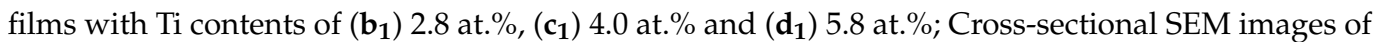
$\left(\mathbf{a}_{2}\right)$ pure DLC and $\left(\mathbf{c}_{\mathbf{2}}\right) \mathrm{Ti}$ (2.8 at.\%)-DLC with corresponding 3D AFM morphologies $\left(\mathbf{b}_{\mathbf{2}}, \mathbf{d}_{\mathbf{2}}\right)$; Scratch curves and their corresponding optical scratch track images of $\left(\mathbf{a}_{3}\right)$ pure DLC film, and Ti-DLC films with Ti content of $\left(\mathbf{b}_{3}\right) 2.8$ at.\% and $\left(\mathbf{c}_{3}\right) 5.8$ at.\% [54].

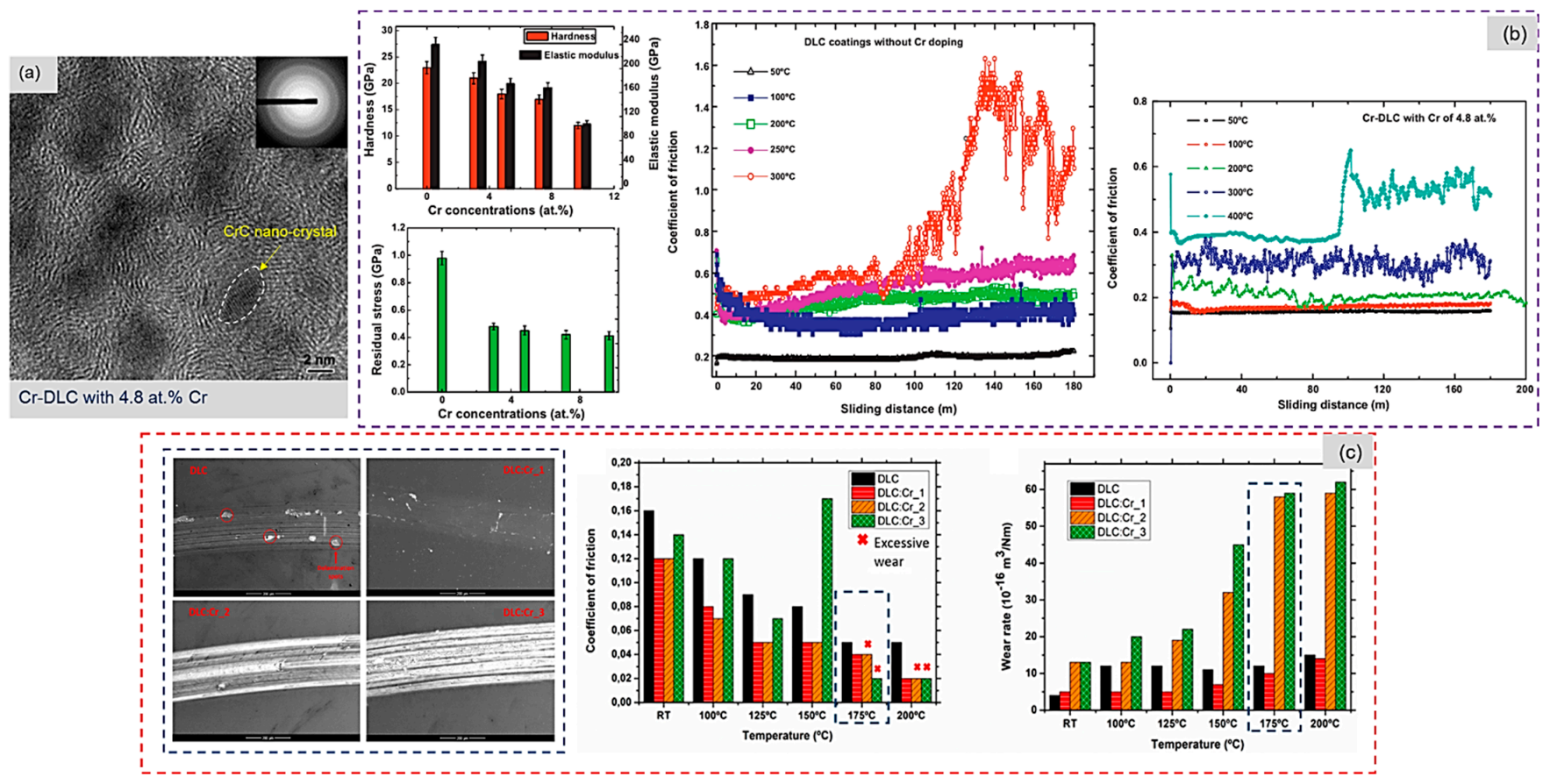

Figure 12. Cr-doped DLC films. (a) Cross-sectional HRTEM of Cr-DLC with 4.8 at.\% Cr [53]. (b) The mechanical properties of Cr-DLC coatings and the temperature-dependent friction coefficient of DLC coatings [55]. (c) Wear tracks tested at $175{ }^{\circ} \mathrm{C}$ and evolution of $\mathrm{CoF}$ and wear rates with the temperatures for samples. DLC:Cr-1 (DLC with Cr 3 at.\%); DLC:Cr-2 (DLC with Cr 9 at.\%); DLC:Cr-3 (DLC with Cr 20 at.\%) [56]. 

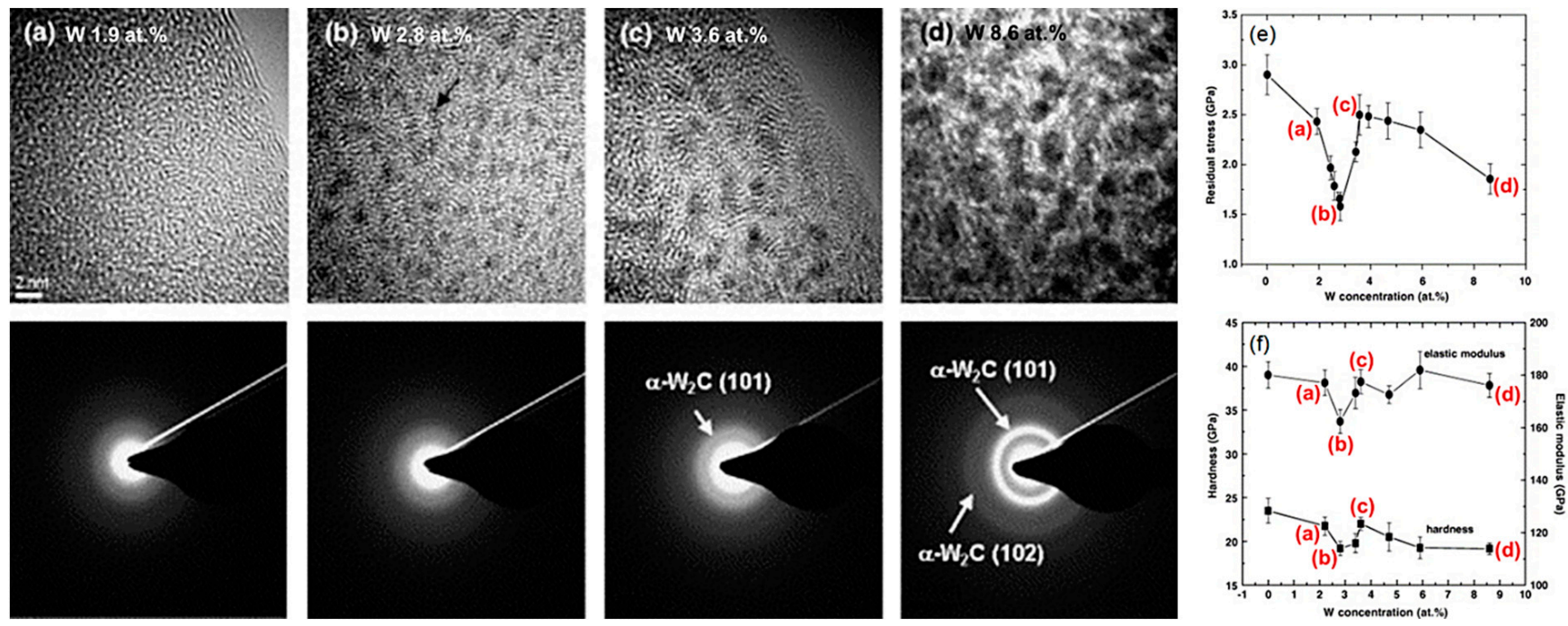

Figure 13. The TEM images and corresponding FFT images of $\mathrm{W}$-doped DLC coatings with $\mathrm{W}$ contents of (a) 1.9 at.\%, (b) 2.8 at.\%, (c) 3.6 at.\%, (d) 8.6 at.\%; residual stress (e) and mechanical properties (f) of W-doped DLC coatings [57].

The introduction of chemical elements strongly bonding with carbon atoms can facilitate the transformation of $\mathrm{sp}^{3}$ to $\mathrm{sp}^{2}$ and break the continuity of the carbon network, resulting in structural ordering, which reduces the mechanical properties and compressive stress [58], since the mechanical properties of hydrogen-free DLC coatings are governed by the carbon hybrid bonding configuration [59].

Some studies $[60,61]$ reported that the doping elements of non-carbide formers in DLC coatings, such as $\mathrm{Al}$ and $\mathrm{Ag}$, improve toughness and absorb internal stresses through the formation of ductile phases. Meanwhile, the tendency of the $\mathrm{sp}^{3}$ bonding in the carbon matrix towards transforming into $\mathrm{sp}^{2}$ bonding causes a decrease in hardness [62]. Yanxia $\mathrm{Wu}$ et al. [63] found that the Ag containing DLC coatings doped with different Ag contents between 3.55 and 11.02 at.\% were synthesized using the medium-frequency unbalanced magnetron sputtering technique, as shown in Figure 14. With an increase in Ag concentration, the amount and size of the nano-crystalline Ag phase embedded in the hydrogenated amorphous carbon matrix increased, which decreased the hardness and internal stress. In particular, with low Ag concentration (3.55 at.\%), the internal stress of the coating is reduced to a low value without a significant decrease in hardness, which enhances the adhesion strength and presents good durability of Ag surface segregation with a low $\mathrm{CoF}$ in vacuum sliding. The excellent tribological performances of Ag-DLC coating were governed by the high hardness and lubrication of DLC coating in combination with the high plasticity, low shear strength and diffusion of the Ag. The addition of non-carbide chemical elements in DLC coating causes the mechanical properties to deteriorate due to the softening effect of chemical elements, breaking the disordered $\mathrm{sp}^{3}$ bonds' cross-linking and causing the conversion of the $\mathrm{sp}^{3}$ hybrid bonding to $\mathrm{sp}^{2}$ bonding.

According to the relationship between the doped chemical elements and the mechanical properties of the DLC coating, a few mechanisms can be obtained as follows:

(1) The significant achievement of the introduction of the chemical elements, regardless of bonding with the carbon atoms, causes a dramatic reduction in the internal compressive stress in the DLC coating by reducing the directionality of the C-C bond, especially for $\mathrm{sp}^{3}$ bonds.

(2) Chemical element doping reduces the hardness and elastic modulus of the DLC coating due to the reconfiguration of the carbon hybrid bonds $\left(\mathrm{sp}^{2}\right.$ and $\left.\mathrm{sp}^{3}\right)$.

(3) The incorporation amount of the different chemical elements generated different effects on the mechanical properties and the internal stress of the DLC coating, mainly by affecting the $\mathrm{sp}^{3}$ cross-linking network. 

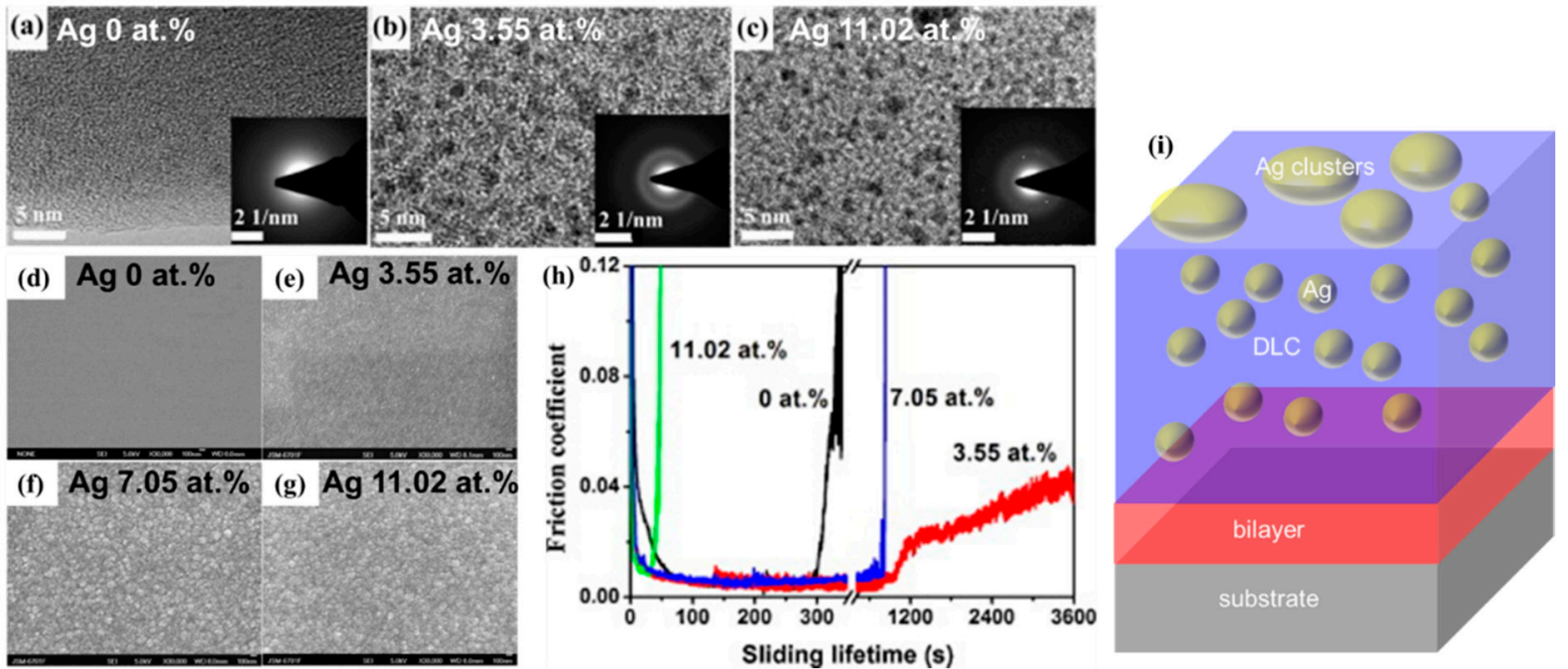

Figure 14. TEM $(\mathbf{a}-\mathbf{c})$, surface morphologies $(\mathbf{d}-\mathbf{g})$ and the wear tests $(\mathbf{h})$ of the Ag-DLC coatings [63]. (i) Schematic representation of Ag surface segregation at wear tracks.

Table 1 illustrates the experimental details of the deposition and tribological processes for DLC films modified by different methods.

Table 1. Deposition parameters and mechanical properties of diamond-like carbon-coated tools.

\begin{tabular}{|c|c|c|c|c|c|c|}
\hline \multirow{2}{*}{ Reference } & \multicolumn{4}{|c|}{ Deposition Parameters } & \multirow{2}{*}{ Main Points } & \multirow{2}{*}{ Reasons/Remarks } \\
\hline & Substrate & Interlayer & Coating & Technique & & \\
\hline [46] & $\begin{array}{l}\text { Tungsten } \\
\text { carbide }\end{array}$ & $\mathrm{TiN}$ & $\begin{array}{l}\text { CrAlSiN- } \\
\text { DLC double } \\
\text { layers } \\
(2.5 \mu \mathrm{m})\end{array}$ & $\begin{array}{l}\text { Cathodic } \\
\text { arc evapo- } \\
\text { ration }\end{array}$ & $\begin{array}{c}\text { Ball-on-disc, dry, } \mathrm{F}_{\mathrm{N}}=5 \mathrm{~N}, \\
\text { WC ball, } \\
\text { CrAlSiN + DLC: HV 5000, } \\
\text { CoF 0.45, better tribological } \\
\text { properties; } \\
\text { CrAlSiN: HV 3100, CoF } 0.55\end{array}$ & $\begin{array}{l}\text { DLC was charactized by } \\
\text { high H and low CoF; } \\
\text { CrAlSiN works supported } \\
\text { this effect. }\end{array}$ \\
\hline [1] & $\begin{array}{l}\text { Tungsten } \\
\text { carbide }\end{array}$ & $\mathrm{TiB}_{2}$ & $\begin{array}{l}\text { DLC-WS } \\
\text { multilayer }\end{array}$ & $\begin{array}{l}\text { FCVA } \\
\text { (graphite) } \\
\text { MS (TiB } 2, \\
\text { WS }_{2} \text { ) }\end{array}$ & $\begin{array}{c}\mathrm{F}_{\mathrm{N}}=5 \mathrm{~N}, \mathrm{WC} \text { ball, } \\
\text { two-layer DLC-WS } \text { ( }_{2}(\mathrm{CoF} \\
\text { 0.05): better tribological } \\
\text { properties; } \\
\text { DLC-WS } \\
\text { CoFs (up to } 0.5 \text { ), rapid } \\
\text { failure }\end{array}$ & $\begin{array}{l}\text { The presence of more } \\
\text { interfaces increases the } \\
\text { internal stress, changing the } \\
\text { failure from ductile to } \\
\text { brittle. }\end{array}$ \\
\hline [51] & $\begin{array}{c}\text { Stainless } \\
\text { steel MECA } \\
\text { 8ND }\end{array}$ & $\begin{array}{c}\# 1 \mathrm{Cr} / \mathrm{CrN} / 50 \times \mathrm{CrN} / \mathrm{C} ; \\
\# 2 \mathrm{Cr} / \mathrm{CrN} / 50 \times \mathrm{Cr} / \mathrm{C} ; \\
\# 3 \mathrm{Cr} / 50 \times \mathrm{Cr} / \mathrm{C} ; \\
\# 4 \mathrm{Cr} / 100 \times \mathrm{Cr} / \mathrm{C}\end{array}$ & $\begin{array}{l}\text { DLC top } \\
\text { layer }\end{array}$ & DCMS & $\begin{array}{c}\text { Ball-on-disc, } \mathrm{F}_{\mathrm{N}}=5 \mathrm{~N}, \\
\text { alumina ball, } \\
\text { \#1: delaminated parts. } \\
\text { \#2: buckling/spallation. } \\
\text { \#3: higher adherence. } \\
\text { \#4: a few radial cracks. }\end{array}$ & $\begin{array}{l}\text { Lower adherence induced } \\
\text { the buckling/spallation }\end{array}$ \\
\hline [52] & $\begin{array}{c}\mathrm{Si}(100) \\
\text { AISI } 440 \mathrm{C} \\
\text { steel }\end{array}$ & $\begin{array}{c}\text { CrN/DLC alternating } \\
\text { layers }\end{array}$ & Cr-DLC & PECVD & $\begin{array}{c}\text { Ball-on-disc, } \mathrm{F}_{\mathrm{N}}=3 \mathrm{~N} \text {, AISI } \\
440 \mathrm{C} \text { ball and TC4 ball, } \\
\text { Single CrN: H } 26 \mathrm{GPa}, \\
\text { adhesion } 70 \mathrm{~N} \text {; Single DLC: } \\
\text { H } 17 \mathrm{GPa} \text {, adhesion } 70 \mathrm{~N} ; \\
\text { CrN/DLC/Cr-DLC: H } \\
10 \mathrm{GPa} \text {, adhesion } 30-35 \mathrm{~N} ; \\
\text { wear rate: single DLC > } \\
\text { single crn > } \\
\text { CrN/DLC/Cr-DLC }\end{array}$ & $\begin{array}{l}\text { A combination of lubricant } \\
\text { and strong support effects } \\
\text { corresponding to DLC and } \\
\text { CrN, and multilayer design } \\
\text { against crack propagation. }\end{array}$ \\
\hline
\end{tabular}


Table 1. Cont.

\begin{tabular}{|c|c|c|c|c|c|c|}
\hline \multirow{2}{*}{ Reference } & \multicolumn{4}{|c|}{ Deposition Parameters } & \multirow{2}{*}{ Main Points } & \multirow{2}{*}{ Reasons/Remarks } \\
\hline & Substrate & Interlayer & Coating & Technique & & \\
\hline$[36]$ & $\begin{array}{l}\text { AISI } 304 \\
\text { austenitic } \\
\text { steel }\end{array}$ & - & $\begin{array}{l}\mathrm{TiN} / \mathrm{a}-\mathrm{C}: \mathrm{H} \\
\text { multilayer } \\
\quad \text { film }\end{array}$ & PECVD & $\begin{array}{l}\text { ball-on-disc, } \mathrm{F}_{\mathrm{N}}=5 \mathrm{~N}, \\
\qquad \mathrm{Al}_{2} \mathrm{O}_{3} \text { ball, } \\
8 \times \mathrm{TiN} / \mathrm{a}-\mathrm{C}: \mathrm{H} \text { r-1:1 and 1:2: } \\
\mathrm{H} 17 \mathrm{GPa} \text {, critical load to } \\
\text { fracture } 205-210 \mathrm{mN} \text {, good } \\
\text { adhesion to the substrate } \\
\text { and lowest wear. }\end{array}$ & $\begin{array}{l}\text { The excellent tribological } \\
\text { properties of a-C:H and the } \\
\text { high fracture toughness of } \\
\text { multilayer architecture. }\end{array}$ \\
\hline [37] & $\begin{array}{c}\text { Si (100) } \\
\text { high-speed } \\
\text { steel (HSS) }\end{array}$ & $\begin{array}{c}\mathrm{Cr} / \mathrm{CrCx} / \mathrm{CrC} \\
\text { interlayer }\end{array}$ & $\begin{array}{l}\text { TiAlN/DLC } \\
\text { multilayer }\end{array}$ & HiPIMS & $\begin{array}{c}\text { Single DLC }(-150 \mathrm{~V}) \text { : } \\
\text { adhesion } 55 \mathrm{~N} ; \\
\text { TiAlN/DLC multilayer: } \\
4.5 \mu \mathrm{m} \text { thick, excellent } \\
\text { adhesion }\left(\mathrm{L}_{\mathrm{C}}=63 \mathrm{~N}\right)\end{array}$ & $\begin{array}{l}\text { The smoother surface } \\
\text { formed at higher bias } \\
\text { contributes to ion migration } \\
\text { and diffusion, enhancing } \\
\text { the adhesion. }\end{array}$ \\
\hline$[34]$ & $\begin{array}{l}\text { Si }(111) \\
304 \\
\text { stainless } \\
\text { steel }\end{array}$ & WC & $\begin{array}{l}\text { Alternating } \\
\text { WC and DLC } \\
\text { with varying } \\
\text { periods: } 1,5, \\
10,20,50,100, \\
150 \text { and } 200 .\end{array}$ & MS & $\begin{array}{c}\mathrm{F}_{\mathrm{N}}=1 \mathrm{~N}, \mathrm{Si}_{3} \mathrm{~N}_{4} \text { ball, } \\
\text { multilayered WC/DLC: } \\
\mathrm{H}>45 \mathrm{GPa}, \mathrm{H} / \mathrm{E} \sim 0.15 \text {, high } \\
\text { durability in wear, without } \\
\text { any cracking or } \\
\text { delamination in dry sliding. } \\
\text { Low-temperature annealing } \\
\left(<400{ }^{\circ} \mathrm{C}\right) \text { gives an increase } \\
\text { in the } \mathrm{H} \text { and } \mathrm{E} .\end{array}$ & $\begin{array}{l}\text { The diffusion of carbon in } \\
\text { the DLC and WC layers at } \\
\text { low temperatures formed an } \\
\text { intermixing of atom } \\
\text { interlayers. The multilayer } \\
\text { architecture inhibits the } \\
\text { coalescence of vacancies. }\end{array}$ \\
\hline [55] & $\begin{array}{l}\mathrm{Si}(111) \\
\text { WC-Co }\end{array}$ & - & $\begin{array}{c}\mathrm{Cr} \\
(3 / 4.8 / 7.2 / \\
9.7 \text { at. } \%)-\mathrm{DLC}\end{array}$ & $\begin{array}{l}\text { Middle- } \\
\text { frequency } \\
\text { MS }\end{array}$ & $\begin{array}{l}\text { Ball-on-disc, } \mathrm{F}_{\mathrm{N}}=10 \mathrm{~N}, 319 \\
\text { Al ball, } \\
\text { Cr-DLC: the } \mathrm{sp}^{3} / \mathrm{sp}^{2} \text { ratio, } \\
\mathrm{H} \text { and } \mathrm{E} \text {, and stress decrease } \\
\text { with an increase in Cr, low } \\
\text { Cr-doped DLC: stable } \\
\text { friction }\left(400{ }^{\circ} \mathrm{C}\right) \text {. Undoped } \\
\text { DLC: higher CoF }\end{array}$ & $\begin{array}{l}\mathrm{Cr}-\mathrm{C} \text { or } \mathrm{Cr} \text { nanocluster } \\
\text { reduces the compressive } \\
\text { stress by breaking the } \\
\text { carbon bonds. }\end{array}$ \\
\hline$[50]$ & p-type $\mathrm{Si}$ & $\begin{array}{l}\mathrm{Ni} \text { and } \mathrm{Cr} \text { layers with } \\
10,20 \text { and } 40 \mathrm{~nm}\end{array}$ & DLC-H & PECVD & $\begin{array}{c}\text { DLC on Cr: smoother } \\
\text { morphology, more sp } \\
\text { bonding, residual stress } \\
0.29 \mathrm{GPa} \text {, lower CoF and } \\
\text { higher H (27 GPa). } \\
\text { DLC on Ni: residual stress } \\
1.62 \mathrm{GPa} \text {. }\end{array}$ & $\begin{array}{l}\text { The lower surface } \\
\text { roughness of the interlayer } \\
\text { contributes to the atomic } \\
\text { diffusion of DLC films and } \\
\text { the high adhesion strength. }\end{array}$ \\
\hline [39] & $\begin{array}{l}\text { YG6, Si } \\
(100)\end{array}$ & - & $\begin{array}{l}\text { Multilayer } \\
\text { ta-c film }\end{array}$ & FCVA & $\begin{array}{c}\text { Ball-on-disc, } \mathrm{F}_{\mathrm{N}}=5 \mathrm{~N}, \\
\mathrm{Al}_{2} \mathrm{O}_{3} \text { ball, } \\
\text { multilayer ta-C: } \mathrm{CoF} \\
\text { 0.06-0.08, lowest } \mathrm{CoF}(0.06) \\
\text { and wear rate. }\end{array}$ & $\begin{array}{c}\mathrm{H} / \mathrm{E} \text { acts as a guideline to } \\
\text { evaluate the wear } \\
\text { performance. H is mainly } \\
\text { dependent on the soft DLC } \\
\text { layer. }\end{array}$ \\
\hline$[40]$ & $\begin{array}{c}\text { M2 tool } \\
\text { steel, } \mathrm{Si} \\
(100)\end{array}$ & $\begin{array}{l}\text { Metal layer } \mathrm{Cr} \text {, } \\
\text { gradient layer } \mathrm{Cr} / \mathrm{C} \text {. }\end{array}$ & $\begin{array}{l}\text { Alternating } \\
\text { soft and hard } \\
\text { DLC layers } \\
\text { multilayer. }\end{array}$ & $\begin{array}{l}\text { Closed- } \\
\text { field } \\
\text { unbalanced } \\
\text { MS }\end{array}$ & $\begin{array}{c}\text { Ball-on-disc, } \mathrm{F}_{\mathrm{N}}=10,20,40, \\
80 \mathrm{~N}, \mathrm{WC}-6 \% \text { Co ball; single } \\
\text { DLC: brittleness failure }\left(\mathrm{F}_{\mathrm{N}}\right. \\
>20 \mathrm{~N}), \mathrm{K}_{\mathrm{IC}} 0.6 \mathrm{MPa} \mathrm{m}^{1 / 2}, \\
\text { CoF } 0.08-0.1 . \text { Multilayer } \\
\text { DLC: better wear resistance } \\
\left(\mathrm{F}_{\mathrm{N}}=80 \mathrm{~N}\right), \mathrm{K}_{\mathrm{IC}} 2.7 \mathrm{MPa} \\
\mathrm{m}^{1 / 2}, \mathrm{CoF} 0.13 .\end{array}$ & $\begin{array}{c}\text { The interfaces between hard } \\
\text { and soft DLC layers stop the } \\
\text { crack propagation, acting as } \\
\text { barriers. }\end{array}$ \\
\hline [63] & $\begin{array}{c}\text { Stainless } \\
\text { steel, Si } \\
\text { (111) }\end{array}$ & Si interlayer & $\begin{array}{l}\text { DLC films } \\
\text { with Ag } \\
\text { concentration } \\
\text { of } 0 \text { to } \\
11.02 \text { at. } \%\end{array}$ & PECVD & $\begin{array}{c}\text { Ball-on-disc, } \mathrm{F}_{\mathrm{N}}=5 \mathrm{~N}, \mathrm{GCr} \\
15 \text { steel ball, } \\
\mathrm{sp}^{2} \text { increased with the } \\
\text { addition of Ag. } \\
3.55 \text { at. } \% \text { Ag-DLC: low } \\
\text { compressive stress, high } \\
\text { adhesion strength, low CoF, } \\
\text { the longest sliding lifetime } \\
\text { in a vacuum. }\end{array}$ & $\begin{array}{l}\text { Ag nanocluster releases the } \\
\text { residual stress, acting as a } \\
\text { buffer site, and tends to } \\
\text { form on the surface, } \\
\text { reducing the friction. }\end{array}$ \\
\hline$[56]$ & $\begin{array}{l}\text { SS304, Si } \\
\quad(100)\end{array}$ & WC interlayer & $\begin{array}{l}\text { Cr-doped } \\
\text { DLC films } \\
\text { concentra- } \\
\text { tions of } 3,9 \text {, } \\
20 \text { at. } \%\end{array}$ & $\begin{array}{l}\text { HiPIMS } \\
\quad(\mathrm{Cr}) \\
\text { DC-pulsed } \\
\text { technology } \\
\quad(\mathrm{C})\end{array}$ & $\begin{array}{c}\text { Ball-on-disc, } \mathrm{F}_{\mathrm{N}}=5 \mathrm{~N}, \\
\mathrm{Al}_{2} \mathrm{O}_{3} \text { ball, } \\
\text { Cr-doped } \mathrm{DLC} \text { : more plastic } \\
\text { behavior, } \mathrm{H}_{\max }=30 \mathrm{GPa}, \\
\text { lower } \mathrm{CoF}, \text { better } \\
\text { high-temperature frictional } \\
\text { behavior. }\end{array}$ & $\begin{array}{l}\text { Cr- } C \text { bonds release the } \\
\text { distortion of } C-C \text { bonds and } \\
\text { decrease the residual stress. } \\
\text { The transfer carbon } \\
\text { tribo-layer reduces wear. }\end{array}$ \\
\hline
\end{tabular}


Table 1. Cont.

\begin{tabular}{|c|c|c|c|c|c|c|}
\hline \multirow{2}{*}{ Reference } & \multicolumn{4}{|c|}{ Deposition Parameters } & \multirow{2}{*}{ Main Points } & \multirow{2}{*}{ Reasons/Remarks } \\
\hline & Substrate & Interlayer & Coating & Technique & & \\
\hline [57] & Si (100) & - & $\begin{array}{l}\text { DLC with W } \\
\text { concentration } \\
\text { ranging from } \\
1.9 \text { to } 8.6 \text { at. } \%\end{array}$ & PECVD & $\begin{array}{l}\text { W-DLC: when W } \\
\text { concentration increased, the } \\
\text { residual stress reduced, then } \\
\text { increased, and then reduced } \\
\text { again, } \\
\text { without any loss of the } \\
\text { mechanical properties. }\end{array}$ & 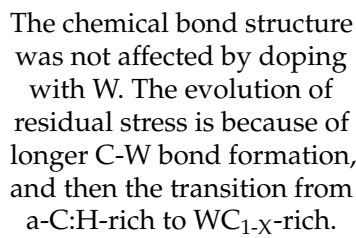 \\
\hline
\end{tabular}

\section{Cutting Performance of DLC-Coated Tools}

The literature reported that the machining performance of DLC-coated tools is dictated by the material to be machined and the cutting condition. The durability, wear rate, machined surface quality and dimensional precision can be used to evaluate the cutting performance of the tools. To improve the cutting performance of the DLC-coated tools, the failure mechanism of the coating in the machining process needs to be clarified; therefore, a large number of studies reported the cutting properties of the DLC coating in cutting various materials. Figure 15 shows the systematic diagram of the machining application of DLC-coated tools for various materials.

Machining application of DLC coated tools for various materials

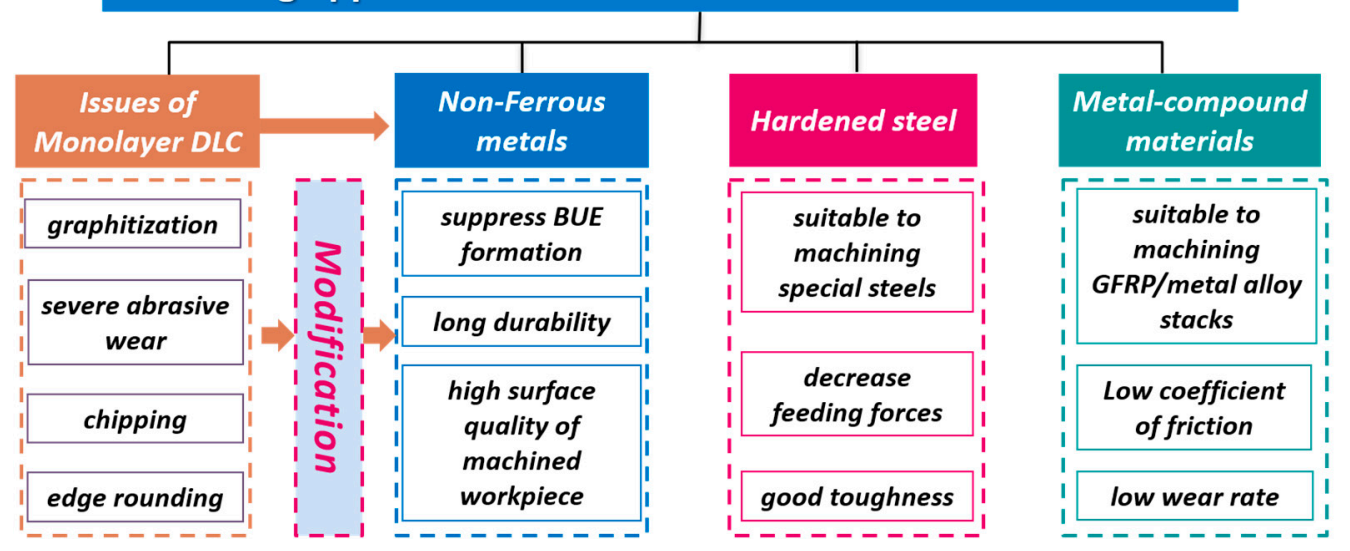

Figure 15. Systematic diagram of machining application of DLC-coated tools for various materials.

\subsection{Non-Ferrous Metals Cutting Performance}

Studies [64] stated that during the dry drilling of aluminum alloys, drill chips easily adhered to the main cutting edges, rake face and flutes of the drill to block its evacuation, owing to the low melting point and elastic modulus of aluminum alloys, resulting in rapid drill failure. Therefore, the challenge relating to machining aluminum alloys is the presence of BUE due to the strong adhesion between aluminum and the tool material, and the poor surface quality because of the abrasion of hard particles on the aluminum matrix [44]. This situation demanded that the cutting tools featured an outer smooth layer with antiadhesion and lubricant effects and an inner hard layer with high wear resistance [44]. A few studies [33,65-69] showed that DLC-coated tools are good candidates in machining aluminum alloys.

There are some studies into the applications of DLC-coated tools in milling aluminum alloys, as illustrated in Figure 16. Tomasz L. Brzezinka et al. [1] reported that a desirable cutting performance was obtained by two-layer DLC-WS $\mathrm{W}_{2}$-coated milling inserts with a low CoF (0.05) in face milling of Al-10Si. Depositing the DLC layer onto the $\mathrm{WS}_{2}$ layer can significantly improve the cutting lifetime compared to $\mathrm{TiB}_{2}$, owing to the desirable lubrication of $\mathrm{WS}_{2}$ in the tool-chip interaction, and the better wear resistance and protection against aluminum sticking of the DLC layer. On the other hand, the formation of a transfer 
lubricant layer at the contact area contributed to reducing the friction force and protecting the tool surface. Haruyo Fukui et al. [69] reported that in the case of dry machining of the aluminum alloys, the DLC-coated tools improve the cutting performance, service life and machined surface finish compared to the uncoated tools. The DLC coating provides low $\mathrm{CoF}$ and lubricant effects to reduce the cutting temperature and resistance. In addition, the DLC coating provides excellent anti-adherence against aluminum alloy to avoid the formation of a BUE. The finite element method (FEM) simulation of the cutting process verified the significant reduction in the cutting force and friction heat for the DLC coating, accompanied by chips of a small thickness and curl diameter.

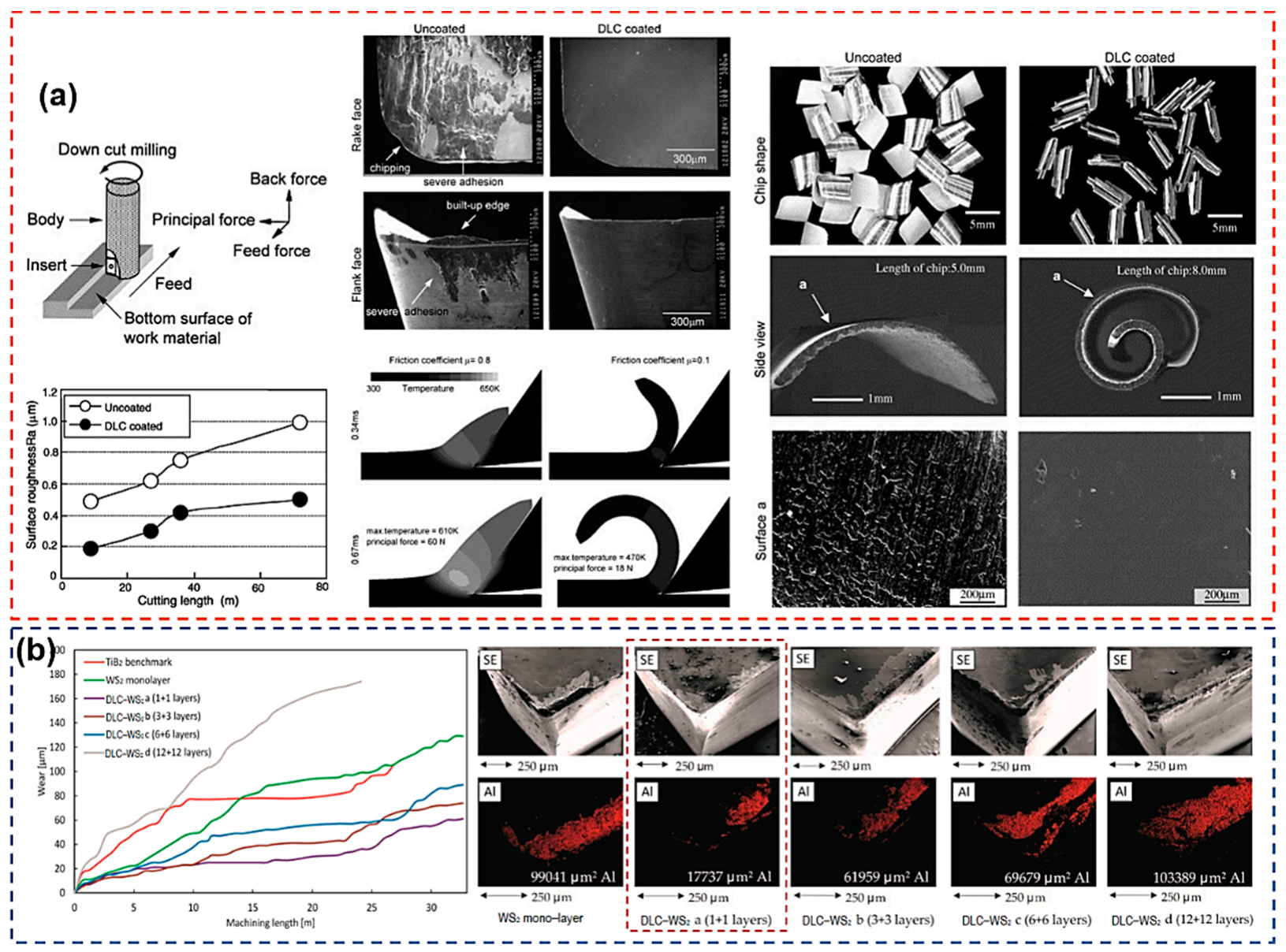

Figure 16. (a) Schematic sketch of milling, SEM of rake and flank face after the dry milling AlCu2.5Si18 alloy, FEM simulation results, types of chips, and changes in machined surface roughness [69]. (b) Tool wear curves of inserts with DLC-WS 2 coatings and aluminum element mapping images of the flank face of the mill insert [1].

The applications of DLC-coated tools in drilling have been investigated, as shown in Figure 17. W.M. Silva et al. [33] reported that the DLC-coated tool with a silicon transition layer exhibited excellent cutting performance in drilling holes for aluminum alloys. When drilling 1800 holes, the smaller radial deviations were obtained by the DLC-coated tool compared with the uncoated tool, due to a lower CoF against aluminum for the DLCcoated tool. The DLC-coated tool provided all of the holes with low roughness. The wear of the DLC-coated drill occurred at the drill edge without the cover of the DLC coating, whereas all of the cutting edges suffered severe wear for the uncoated drills. The method of minimum quantity lubrication (MQL) is an environmentally friendly cutting technique and can also provide a more stable process over dry cutting. Sukanta Bhowmick et al. [64] reported that when drilling 319 aluminum alloy under $\mathrm{H}_{2} \mathrm{O}-\mathrm{MQL}$ and dry conditions, the mechanical properties of DLC-coated and DLC-H-coated HSS drills, combined with 
uncoated tools, were evaluated from the thrust force and drilling torque. The hardness of DLC-H and DLC coatings were 17.9 and 14.5 GPa, respectively. Under dry conditions, the average drilling torque of the uncoated HSS drill increased from 2.01 to $4.11 \mathrm{Nm}$, corresponding to the 1st to the 49 th hole, followed by drill failure. The H-DLC-coated drills increased from 1.72 to $2.11 \mathrm{Nm}$ across a total of 150 holes with the highest thrust force of $224 \mathrm{~N}$. The DLC-coated HSS drills increased from 1.89 to $2.47 \mathrm{Nm}$ for a total of 150 holes with the largest thrust force of $256 \mathrm{~N}$. Under the $\mathrm{H}_{2} \mathrm{O}-\mathrm{MQL}$ conditions, the uncoated drill showed a gradual increase in average torque (15\%) from 1.67 to $1.92 \mathrm{Nm}$ over 150 holes. The increase in the average torque of the DLC-H coated drills was from 1.48 to $1.69 \mathrm{Nm}$ for all 150 holes, with the highest thrust force of $221 \mathrm{~N}$. The drills with a DLC coating exhibited an average torque of $1.65 \mathrm{Nm}$, with the highest thrust forces of $175 \mathrm{~N}$. The average torque of the DLC-H-coated drill compared favorably with that of the uncoated drills in dry and $\mathrm{H}_{2} \mathrm{O}-\mathrm{MQL}$ drilling. During $\mathrm{H}_{2} \mathrm{O}-\mathrm{MQL}$ drilling, the DLC coating presented excellent aluminum anti-adhesion and a steadier drilling process in comparison to DLC-H, with the smallest BUE formation. The drilling performance of DLC-coated tools is better than that of DLC-H in $\mathrm{H}_{2} \mathrm{O}-\mathrm{MQL}$ conditions. H. Hanyu et al. [70] reported that the chemical vapor deposit (CVD) diamond tools with the DLC coating achieved the performance of the lubrication effect of the DLC coating and the high wear resistance of the CVD diamond coating. They confirmed that the DLC on CVD diamond was characterized by a low CoF and excellent anti-sticking against aluminum alloy, which gives them longer durability in drilling the aluminum alloy than the uncoated ones.
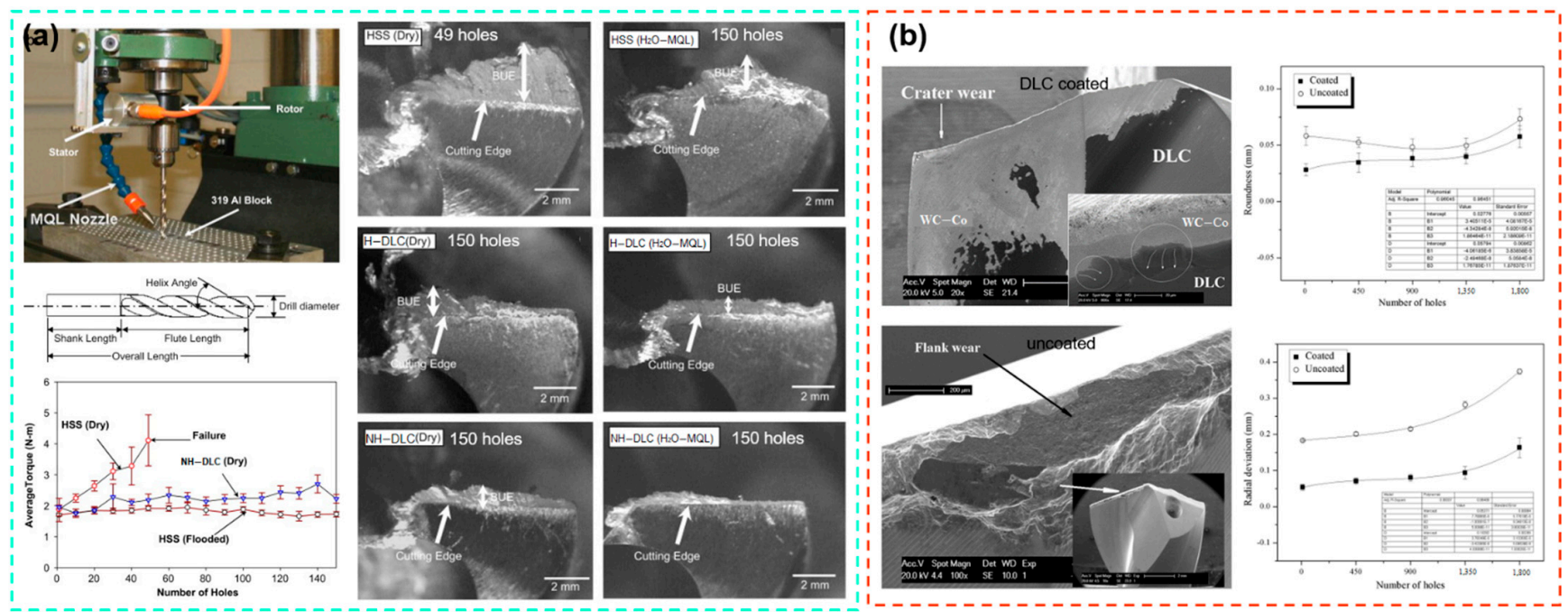

Figure 17. (a) Experimental set-up and geometry of twist dill, comparison of average torque, and optical images of drill cutting edges [64]. (b) Front view of drills after drilling 1800 holes, and evaluation of the roundness and radial deviation [33].

W. Henderer et al. [44] designed a multilayer DLC-H coating of a TiSiN base layer with high hardness and a $\mathrm{CrC} / \mathrm{a}-\mathrm{C}: \mathrm{H}$ top layer with superior friction reduction, used as the cutting tools for machining aluminum silicon. Compared with $\mathrm{TiN}+\mathrm{CrC} / \mathrm{C}$ - and DLC-coated taps, TiSiN $+\mathrm{CrC}_{X} / \mathrm{C}$-coated taps showed a better tribological performance due to a low $\mathrm{CoF}$ and high hardness.

The turning application of the DLC-coated tools is shown in Figure 18. Mingjiang Dai et al. [65] stated that the diamond-coated insert exhibited a strong advantage for cutting aluminum alloy in comparison with the uncoated and DLC-coated inserts, showing a much longer tool life than that of the uncoated insert, which was 55 times longer for cutting Al-Si alloy and 27 times longer for cutting aluminum bronze. However, the DLC-coated insert showed a similar tool life for cutting high-Si-Al alloy as the uncoated one, while the tool life was seven times longer for cutting aluminum bronze and 1.5 times longer for machining mid-Si-Al alloy. Santos et al. [70] analyzed the machining performance of 
the cemented carbide cutting tools with the DLC coating in turning for Al-Si alloys. The DLC-coated cutting tools provided a higher machined surface finish and a lower CoF than uncoated tools. The uncoated tools presented an obvious BUE due to strong adhesion with the aluminum, which increased the cutting force, in comparison with the DLC tools.

(a)

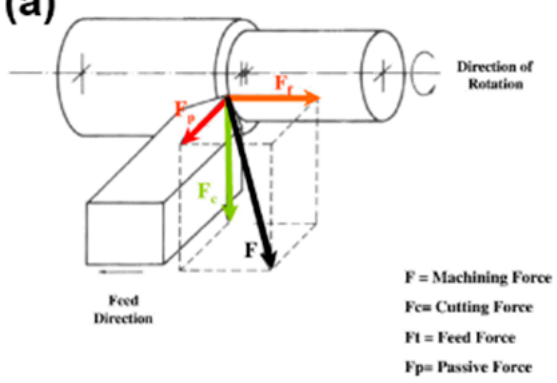

(b)

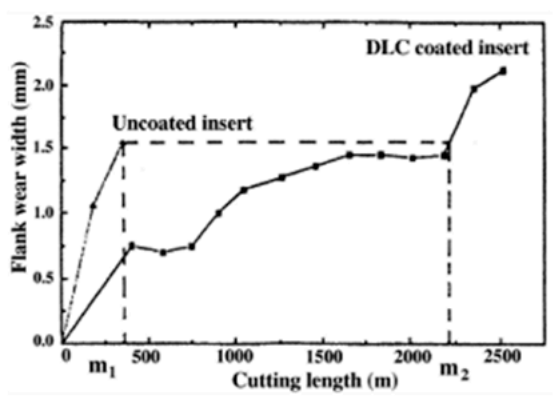

(c) Machining Al-12Si
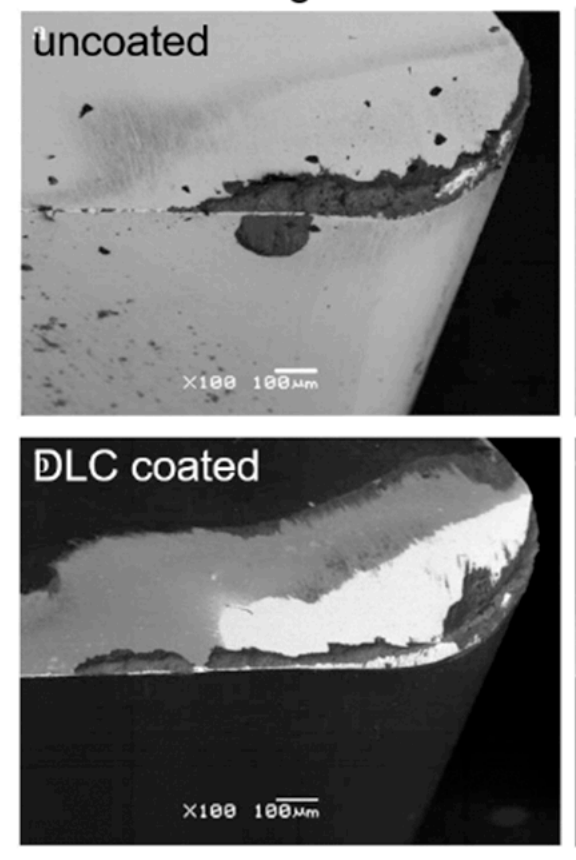
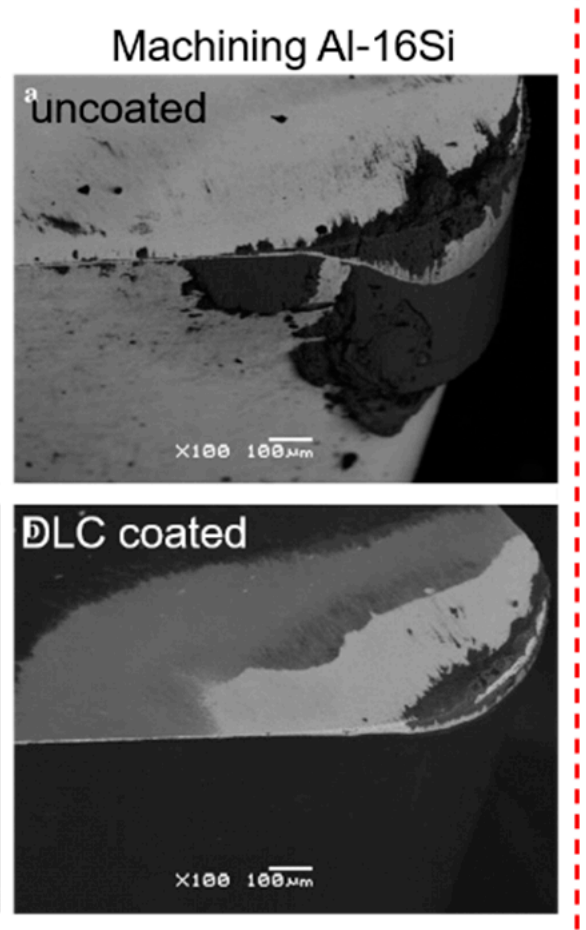

Figure 18. (a) Schematic draw of the turning operation [71]. (b) The wear curves of the inserts [65]. (c) Aluminum adhesion in the tools [71].

Irfan ucun et al. [72] stated that when micro-milling Inconel 718 superalloy by using uncoated and the DLC-coated tools, the coated tools prominently reduced the cutting forces and increased the surface smoothness of the workpiece. Additionally, the DLC-coated tool typically presented better properties against burr formation than the uncoated tool. The experimental results are exhibited in Figure 19.

Ti-6Al-4V alloy is considered to be a difficult-to-machine material and has excellent performance as a biomaterial [73]. The significant challenge related to machining titanium alloy is attributed to the super-high cutting thermal accumulation induced by poor thermal conductivity and the further formation of an ultra-hard surface layer, and a strong tendency to chemically react with almost all tool materials and coatings at cutting temperatures above $500{ }^{\circ} \mathrm{C}[74,75]$. Maksym Ziberov et al. [76] reported that the DLC-coated microtools presented the lowest tool wear during dry micro-milling of the Ti-6Al-4V alloy, compared to the TiAlN-coated and the uncoated microtools, which is attributed to the greater thermal conductivity and lower CoF of the DLC-coated tools, resulting in lower feeding forces, consequently increasing the durability of the microtools. As shown in Figure 20, the heavier wear for uncoated and TiAlN-coated compared to DLC-coated tools was presented under the minimum quantity of lubricant (MQL) rather than under dry machinery; therefore, the application of MQL may not be suitable when micro-milling titanium alloy, which is attributed to the cyclical temperature change at the tool-workpiece interface generated by the discontinuous contact in the cutting process. This cyclic change may be enhanced when cutting fluid is available, which induced thermal fatigue. In addition, at a high cutting temperature, the fluid fails to provide lubrication properly-it only provides cooling. 

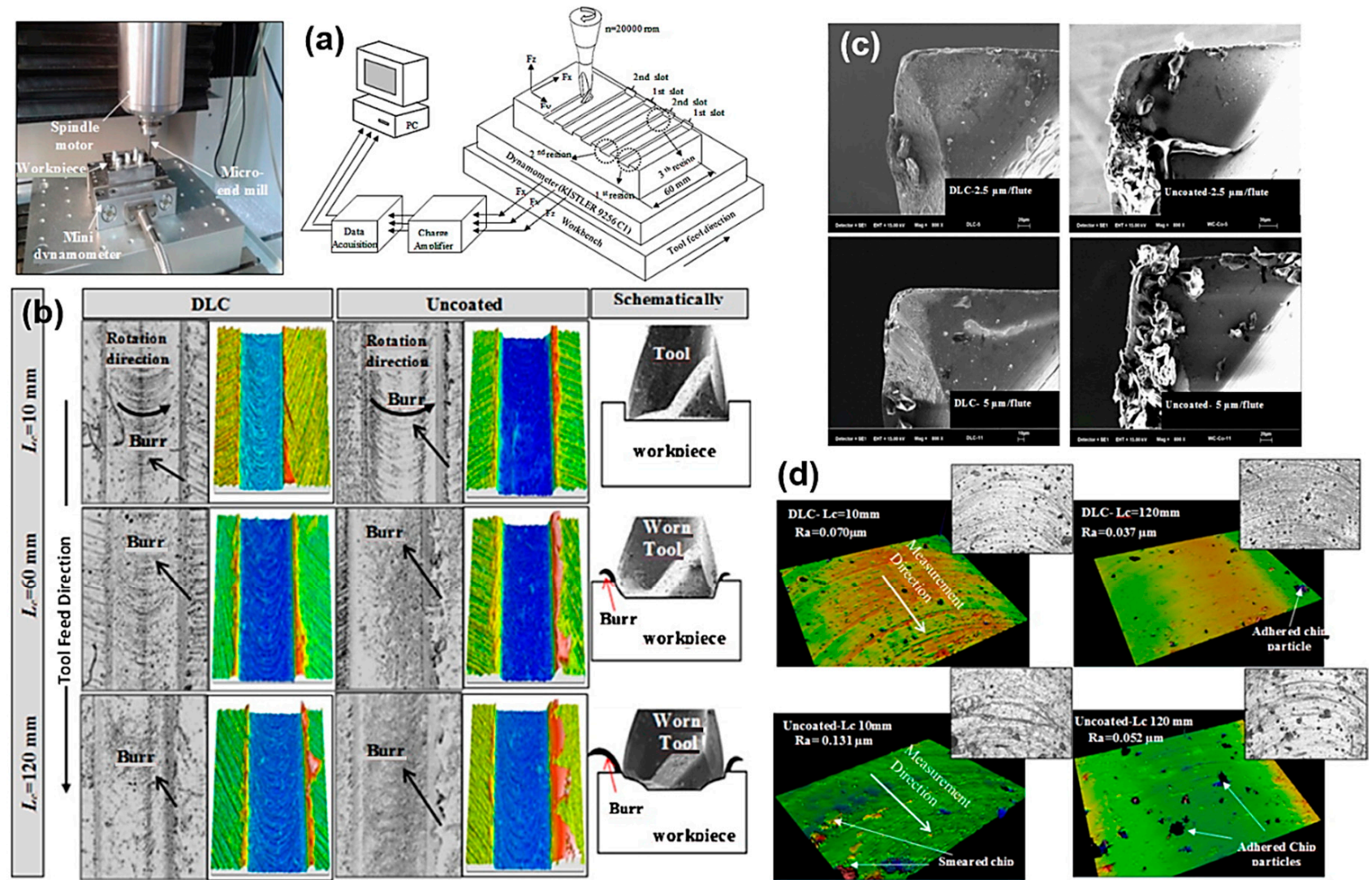

Figure 19. The micro-end milling of Inconel 718 superalloy [72]. (a) Experimental setup. (b) Burr formation. (c) Variation of BUE formation. (d) Three-dimensional topographic images of the machined surfaces.

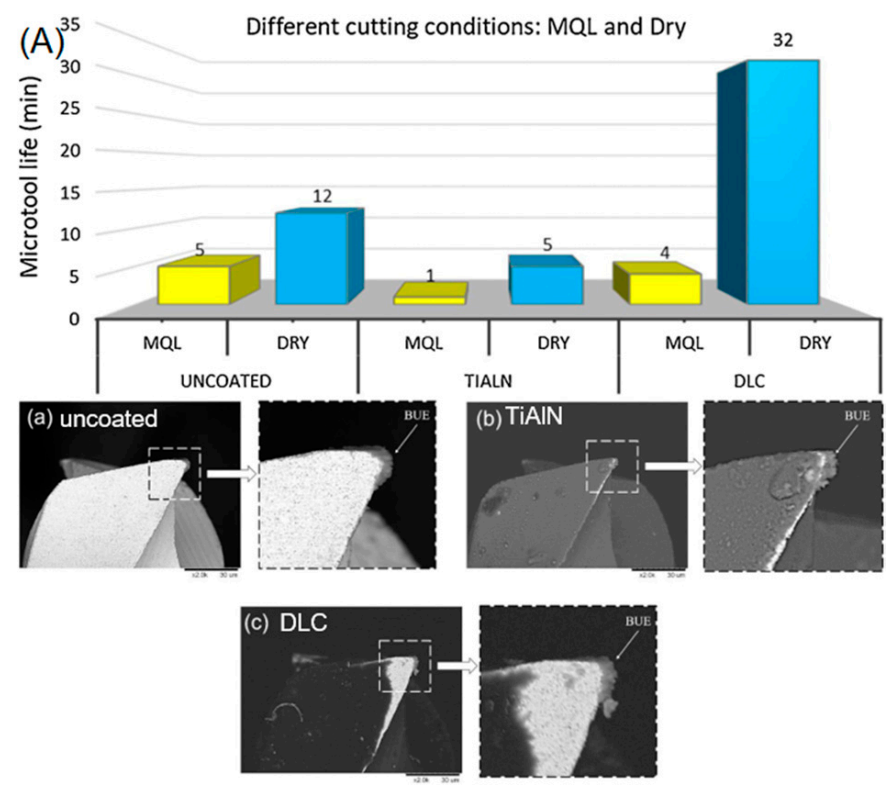

Figure 20. Dry micro-milling of the Ti-6Al-4V alloy [76]. (A) Microtools' working life comparison. Wear morphologies of cutting edge and BUE of (a) uncoated tool, (b) TiAlN coated tool, (c) DLC coated tool under dry conditions.

\subsection{Hardened Steel Cutting Performance}

DLC-coated tools are virtually never employed to machine steel, due to the chemical reaction between carbon and titanium. However, several studies have reported the 
application of tools with DLC coatings in steel machining. The study [77] reported the performance of four tool coatings in the high-speed milling of mold steels NAK80 and SKD61; the DLC-coated tools provided a high-quality machined surface at a small feed rate, but no obvious improvement in durability. Paramet Baowan et al. [32] compared the milling performance of cemented carbide end mills with the DLC and TiAlN coatings on 304 L stainless steel milling under dry conditions. The DLC-coated tools exhibited serious chipping abrasion due to graphitization under relatively high temperature, but contributed to the high surface quality.

However, some studies reported that the DLC-coated tools are also advisable in machining some special steels. Pradeep V Badiger et al. [78] studied the machining performance of a DLC-coated insert in turning highly alloyed steel MDN431 in both wet and dry conditions; the DLC coating is conducive to decreasing feeding forces, improving the quality machined surface, and extending the tool durability. The tap coated with TiAlCNDLC double-layer [79] helped to improve the running-in characteristics of chip removal and is especially suitable for machining austempered ductile iron ADI-900, owing to its good anti-adhesion properties and low CoF. The blind holes in 1.4571 austenitic stainless steel were conducted by taps coated with TiCN-DLC with the high anti-abrasive property of TiCN in combination with the superior lubrication behavior of DLC. G. Fox-Rabinovich et al. [80] stated that the best cutting performance in drilling 7200 holes was obtained by the low-hydrogen DLC coating, which provided a promising surface finish of the drilled holes and low flank wear.

As shown in Figure 21, S.N. Grigoriev et al. [9] reported that a DLC-coated tool with 35 at.\% Si exhibited the highest wear resistance compared with two different Siconcentration (2 and 58 at.\% Si) DLC-coated tools and uncoated ceramic tools in machining AISI 52,100 (HRC 56-58) hardened steel. The tool with the 2 at.\% Si-DLC coating demonstrated a strong tendency to stick to the machined material, and the wear mechanism was adhesive-fatigue. Moreover, the tool with 58 at.\% Si-DLC was apt to form cracks, dominated by transverse cracks propagating into the ceramic substrate. The tool with 35 at.\% Si-DLC presented excellent anti-adhesion to the machined material and good toughness to restrict crack growth.

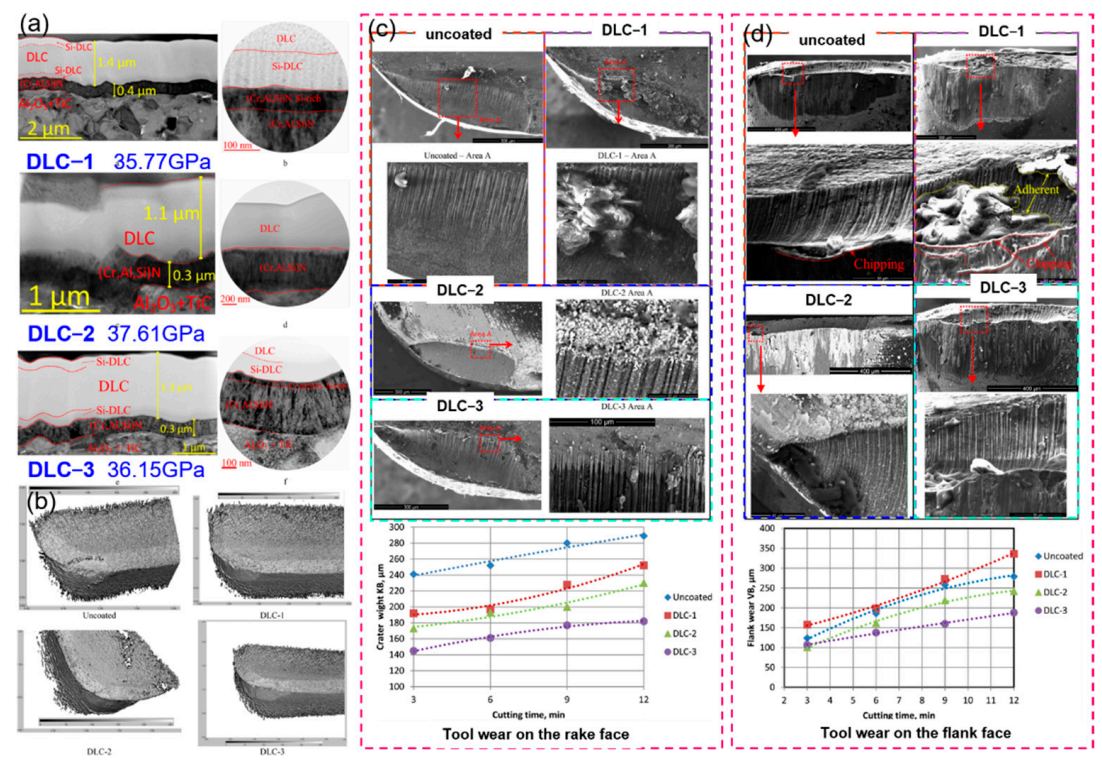

Figure 21. DLC-coated tools in machining AISI 52,100 (HRC 56-58) hardened steel [9]. (a) Crosssectional TEM of the samples. (b) Three-dimensional scans of worn faces. (c) Tool wear on the rake face. (d) Tool wear on the flank face after cutting for $12 \mathrm{~min}$.

As illustrated in Figure 22, Ch Sateesh Kumar et al. [11] compared the dry turning performances of the hydrogenated DLC and $\mathrm{WC} / \mathrm{C}$ multiplayer coatings deposited on $\mathrm{Al}_{2} \mathrm{O}_{3} / \mathrm{TiCN}$ composite ceramic cutting tools in the machining the AISI 52,100 steel 
(62 HRC). Coating delamination occurred in both WC/C and DLC coatings in steel cutting, but was less serious for the tool with WC/C multiplayer coating, which is caused by a higher adhesion strength at the interface between the $\mathrm{WC} / \mathrm{C}$ coating and the substrate $(51 \mathrm{~N})$ compared with the DLC coating $(44 \mathrm{~N})$. In combination with the higher thermal stability, the WC/C coating presents less severe flaking than the DLC coating. Meanwhile, the two kinds of coated tools presented better wear resistance and cutting performance than the uncoated ones.

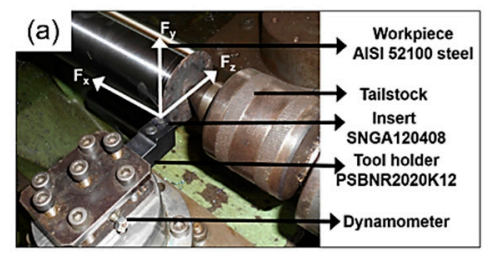

(c) DLC coated

(b)
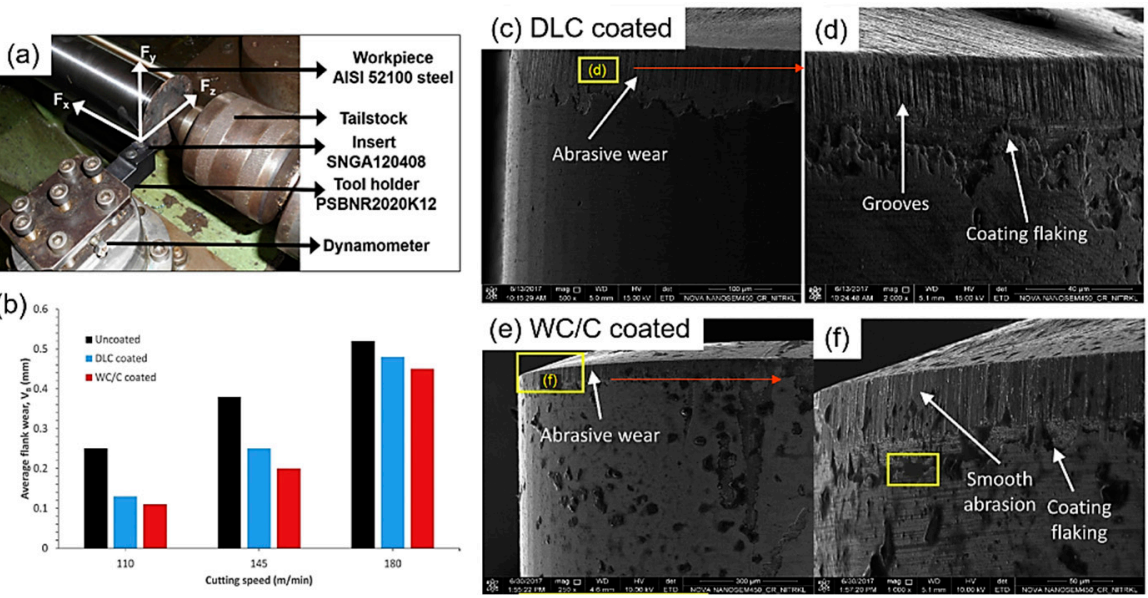

Figure 22. Dry turning performances of the hydrogenated DLC and WC/C multiplayer coatings [11]. (a) Experimental setup for turning. (b) Average flank wear of cutting tools. SEM micrographs of the flank surface for the DLC-coated cutting tool (c) and the WC/C-coated cutting tool (e). (d,f) are the magnified images of the corresponding yellow rectangle area in $(\mathbf{c}, \mathbf{e})$ respectively.

\subsection{Metal-Compound Materials Cutting Performance}

The demand for materials with a high strength weight ratio is growing in the aeronautical, marine and automotive industries, promoting the development and modification of carbon fiber-reinforced plastic (CFRP) composites [81,82]. Multi-material stacks with high overall mechanical properties due to the multiple materials, such as CFRP and metals, are novel modification materials $[83,84]$. However, the machining of multi-material stacks is challenging because of the significant discrepancy between the mechanical properties of each material.

The cutting forces and heat generation during CFRP machining are lower compared to that of metals [85]. In addition, inter-laminar cracking and delamination and poor surface finish are common difficulties that occur in cutting multi-material stacks [85-87]. Meanwhile, the cutting tools suitable for machining CFRP composite materials are inaccessible owing to the low thermal conductivity, composition nonuniformity and abrasive characteristics of the carbon fibers and resin matrix. Extensive research has been conducted to solve these difficulties [83,84,88-94].

Dongcan Zhang et al. [95] reported that the surface topography of DLC films is flatter compared to CVD diamond films, which are characterized by a morphology comrpised octahedral asperities and deep valleys. DLC films showed a lower CoF and stronger adhesion to the WC-Co substrate in comparison with CVD diamond films. The flank abrasion of the tools with a CVD diamond coating maintains a low degree before peeling off from the substrate, whereas the DLC-coated tool always maintains nearly constant wear during the whole turning process. Lei Huang et al. [10] found that the lowest wear rate, longest durability and best quality machined surface were obtained by Ti-DLC/a$\mathrm{C}: \mathrm{H}$ multilayer film with the dominant wear form of abrasive wear in turning GFRP, without obvious diffusion wear and oxidative wear. Figure 23 shows the flank wear of the non-coated, a-C:H-coated and Ti-DLC/a-C:H-coated cutting tools. 


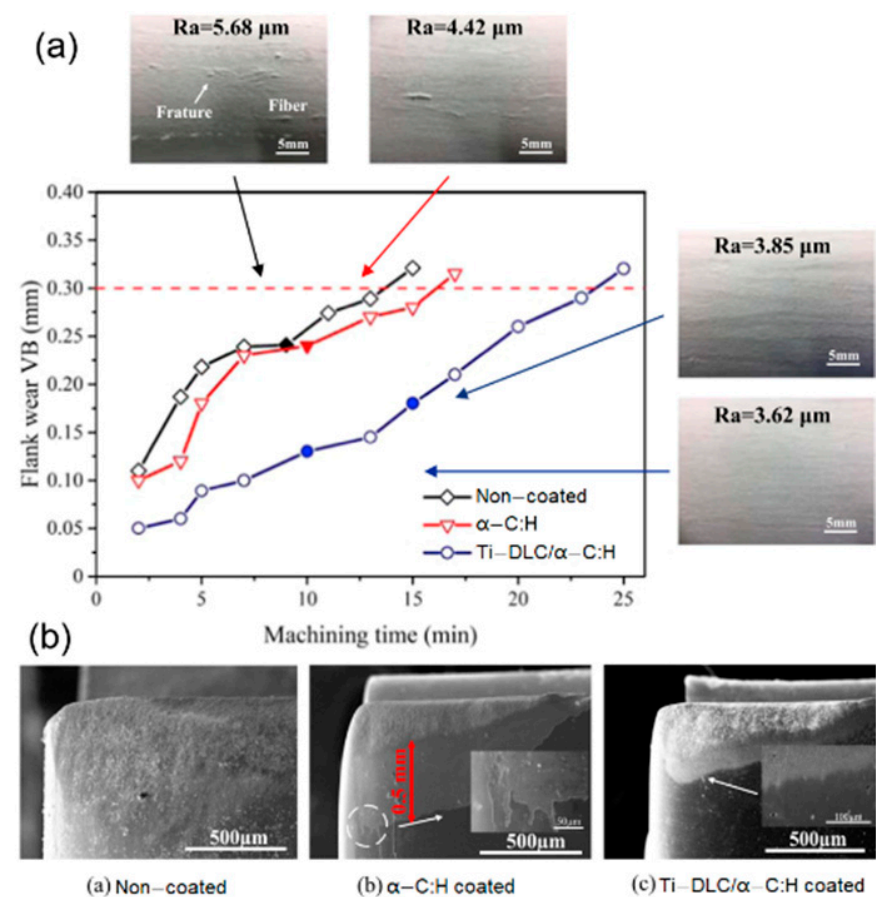

Figure 23. Ti-DLC/a-C:H multilayer film in turning GFRP [10]. (a) The flank wear variation and corresponding machined surface quality. (b) The flank wear images.

A. D'Orazio et al. [81] demonstrated that abrasion is the dominant wear form for TiAlN-coated tools. The flank wear of the TiAlN nanocomposite-coated tool exceeded 2.25 times that of the tool with the DLC coating. The dominant wear mechanism of the tool with the DLC coating is chipping, edge rounding and flank wear, with no built-up edge (BUE) in the drilling of the CFRP / AA7075 stack. The DLC-coated tool displayed a lower peak thrust force and delamination factor value during the drilling of stacks than that of the TiAlN-coated drills, which depends on tool wear and thrust force. In addition, the discrepancy between DCFRPin and DCFRPout using the TiAlN-coated tool is more pronounced than that with the DLC tool, as shown in Figure 24.

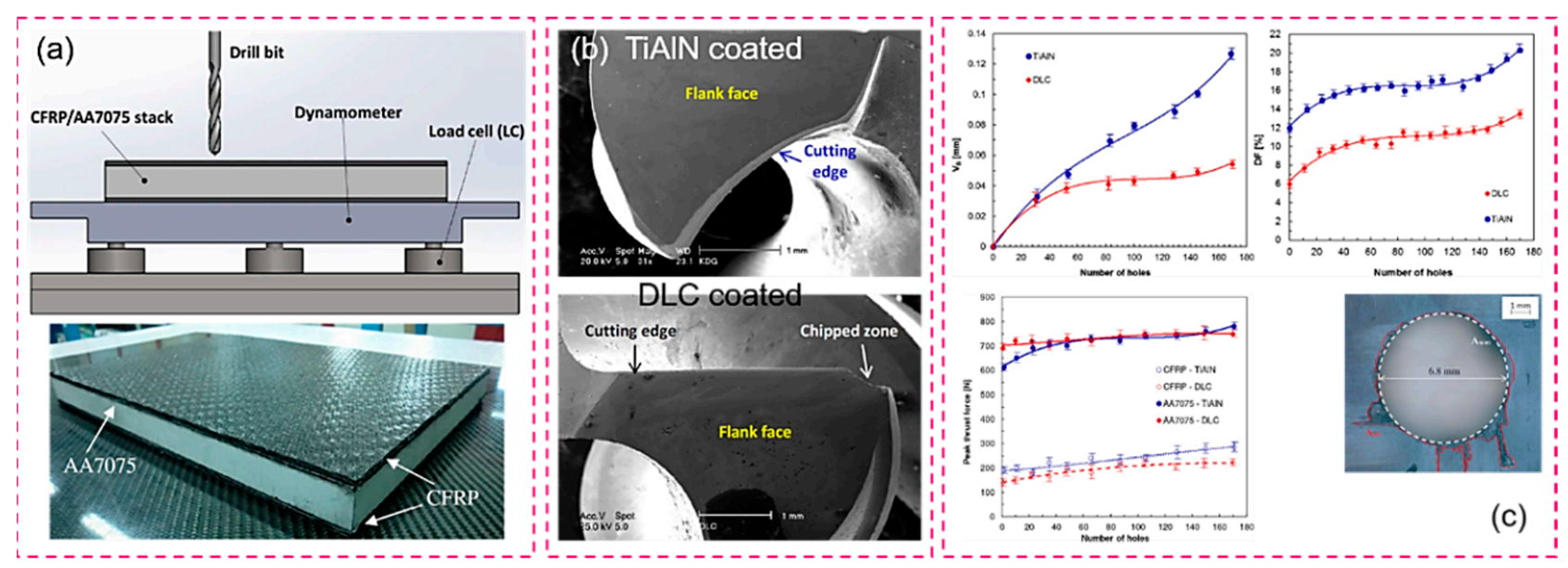

Figure 24. The cutting tools in the drilling of the CFRP/AA7075 stack [81]. (a) Experimental setup for drilling the CFRP/AA7075 stack. (b) Flank face after drilling 170 holes. (c) Evolution of flank wear, thrust force and delamination factor (DF).

Vandevelde et al. [96] investigated the machining performances of DLC- and CVD diamond-coated tools during the dry cutting of a Al-SiC metal matrix composite in compar- 
ison to uncoated cemented carbon tool. The results exhibit that uncoated WC-Co inserts are not recommended for turning the Al-SiC metal matrix composite because of the breakage of the cutting edge and large BUE formation. The tool with the DLC coating suffered from severe abrasive wear of the Al-SiC composite and was worn away quickly. The DLC-coated inserts did not enhance the tool's durability. Relatively better machining performance was obtained by the inserts with the CVD diamond coating, which is a potential substitute for PCD-tipped tools during the dry machining of Al-SiC metal matrix composites.

The deposition details and cutting performance of DLC-coated tools for machining different materials are tabulated in Table 2.

Table 2. Deposition parameters and cutting performance of diamond-like carbon-coated tools.

\begin{tabular}{|c|c|c|c|c|c|c|}
\hline \multirow{2}{*}{ References } & \multicolumn{3}{|c|}{ Deposition Parameters } & \multirow{2}{*}{$\begin{array}{l}\text { Cutting } \\
\text { Material }\end{array}$} & \multirow{2}{*}{$\begin{array}{l}\text { Experimental } \\
\text { Conditions }\end{array}$} & \multirow{2}{*}{ Results/Remarks } \\
\hline & Substrate & Coating & Technique & & & \\
\hline [33] & $\begin{array}{l}\text { Cemented } \\
\text { carbide }\end{array}$ & $\begin{array}{l}\text { Si base } \\
\text { layer +DLC }\end{array}$ & PECVD & $\begin{array}{l}\text { SAE } 323 \\
\text { aluminum } \\
\text { alloy }\end{array}$ & $\begin{array}{l}\text { Drilling }\left(\mathrm{dry}, \mathrm{V}_{\mathrm{C}}=217 \mathrm{~m} / \mathrm{min},\right. \\
11,500 \mathrm{rpm}, 1800 \text { holes })\end{array}$ & $\begin{array}{l}\text { The DLC-coated tools } \\
\text { showed better performance } \\
\text { in dimensional accuracy } \\
\text { and roughness, owing to the } \\
\text { high hardness and low } \\
\text { friction. }\end{array}$ \\
\hline [69] & $\begin{array}{l}\text { Cemented } \\
\text { carbide }\end{array}$ & DLC & $\begin{array}{l}\text { Vacuum arc } \\
\text { discharge }\end{array}$ & $\begin{array}{l}\text { Aluminum } \\
\text { alloy }\end{array}$ & $\begin{array}{l}\text { Milling (dry and wet, } \\
V_{C}=300 \mathrm{~m} / \mathrm{min}, \\
\mathrm{f}=0.15 \mathrm{~mm} / \mathrm{rev})\end{array}$ & $\begin{array}{l}\text { DLC-coated tools reduce the } \\
\text { cutting resistance and } \\
\text { formation of BUE, due to a } \\
\text { low CoF and good } \\
\text { anti-adhering property } \\
\text { without a lubricant. }\end{array}$ \\
\hline [72] & - & DLC & PECVD & $\begin{array}{l}\text { Inconel } 718 \\
\text { nickel-based } \\
\text { superalloy }\end{array}$ & $\begin{array}{l}\text { Micro-milling (dry, spindle } \\
\text { rotation speed = 20,000 rpm) }\end{array}$ & $\begin{array}{l}\text { DLC coating decreased BUE } \\
\text { and burr formation, } \\
\text { generating a low cutting } \\
\text { force and better surface } \\
\text { quality. }\end{array}$ \\
\hline [76] & - & DLC & - & $\begin{array}{l}\text { Ti-6Al-4V } \\
\text { alloy }\end{array}$ & $\begin{array}{l}\text { Micro-milling (dry, spindle } \\
\text { rotation speed = } 6000 \mathrm{rpm})\end{array}$ & $\begin{array}{l}\text { DLC-coated microtools } \\
\text { presented the lowest wear } \\
\text { under dry condition. The } \\
\text { main wear types were edge } \\
\text { rounding and flank wear. }\end{array}$ \\
\hline [9] & $\begin{array}{l}\left(\mathrm{Al}_{2} \mathrm{O}_{3}+\mathrm{TiC}\right) \\
\text { ceramic }\end{array}$ & $\begin{array}{l}(\mathrm{Cr}, \mathrm{Al}, \mathrm{Si}) \mathrm{N}+ \\
\mathrm{DLC}-\mathrm{Si}\end{array}$ & PECVD & $\begin{array}{l}\text { AISI } 52,100 \\
\text { hardened } \\
\text { steel }\end{array}$ & $\begin{array}{c}\text { Turning }\left(\mathrm{V}_{\mathrm{C}}=320 \mathrm{~m} / \mathrm{min}\right. \\
\left.\mathrm{a}_{\mathrm{p}}=0.5 \mathrm{~mm}, \mathrm{f}=0.1 \mathrm{~mm} / \mathrm{rev}\right)\end{array}$ & $\begin{array}{l}\text { The } 35 \text { at.\% Si-DLC-coated } \\
\text { tool exhibited superior wear } \\
\text { resistance due to good } \\
\text { anti-adhesion and crack } \\
\text { propagation resistance. } \\
\text { DLC-coated insert }\end{array}$ \\
\hline [95] & WC-Co & DLC & $\begin{array}{l}\text { Vacuum arc } \\
\text { discharge }\end{array}$ & $\begin{array}{l}\text { Glass fiber } \\
\text { reinforced } \\
\text { plastics } \\
(\text { GFRP) }\end{array}$ & $\begin{array}{l}\text { Turning }\left(\mathrm{V}_{\mathrm{C}}=250 \mathrm{~m} / \mathrm{min}\right. \\
\left.\mathrm{a}_{\mathrm{p}}=1 \mathrm{~mm}, \mathrm{f}=0.1 \mathrm{~mm} / \mathrm{r}\right)\end{array}$ & $\begin{array}{l}\text { presented more severe flank } \\
\text { wear than the } \\
\text { diamond-coated insert, but } \\
\text { diamond films peeled off } \\
\text { sooner. }\end{array}$ \\
\hline [10] & $\begin{array}{l}\text { Cemented } \\
\text { carbide }\end{array}$ & $\begin{array}{l}\text { Ti-DLC/a- } \\
\text { C:H } \\
\text { multilayer } \\
\quad \text { film }\end{array}$ & $\begin{array}{l}\text { MS (Ti-DLC); } \\
\text { linear ion } \\
\text { source } \\
\text { (a-C:H) }\end{array}$ & GFRP & $\begin{array}{c}\text { Turning }(\text { dry, } \\
\mathrm{V}_{\mathrm{C}}=250 \mathrm{~m} / \mathrm{min} \\
\left.\mathrm{a}_{\mathrm{p}}=0.9 \mathrm{~mm}, \mathrm{f}=0.1 \mathrm{~mm} / \mathrm{r}\right)\end{array}$ & $\begin{array}{l}\text { The multilayer film } \\
\text { presented better toughness } \\
\text { and adhesion, the minimum } \\
\text { wear rate, best-machined } \\
\text { surface quality and the } \\
\text { longest tool life. }\end{array}$ \\
\hline [81] & $\begin{array}{l}\text { Tungsten } \\
\text { carbide }\end{array}$ & DLC & - & $\begin{array}{l}\text { Three-layer } \\
\text { CFRP/AA7075 } \\
\text { stacks }\end{array}$ & $\begin{array}{c}\text { Drilling }\left(\mathrm{V}_{\mathrm{C}}=170.8 \mathrm{~m} / \mathrm{min},\right. \\
\mathrm{V}_{\text {spindle }}=8000 \mathrm{rpm}, \text { feed rate } \\
=1300 \mathrm{~mm} / \mathrm{min}, \mathrm{f}=0.2 \\
\mathrm{~mm} / \mathrm{rev})\end{array}$ & $\begin{array}{l}\text { The DLC-coated drill } \\
\text { showed lower wear, } \\
\text { delamination factor and } \\
\text { thrust force. The main wear } \\
\text { mechanism is chipping, } \\
\text { edge rounding and } \\
\text { abrasion. }\end{array}$ \\
\hline [44] & $\begin{array}{l}\text { Cemented } \\
\text { carbide }\end{array}$ & $\begin{array}{c}\mathrm{TiSiN}+ \\
\mathrm{CrC} / \mathrm{a}-\mathrm{C}: \mathrm{H}\end{array}$ & $\begin{array}{l}\text { Hybrid } \\
\text { cathodic } \\
\text { arc/sputter }\end{array}$ & 390 AlSi17 & $\begin{array}{l}\text { Tapping }\left(\mathrm{V}_{\mathrm{C}}=190 \mathrm{~m} / \mathrm{min}\right. \\
\text { water solute coolant })\end{array}$ & $\begin{array}{c}\text { TiSiN }+\mathrm{CrCx} / \mathrm{C} \text {-coated taps } \\
\text { showed a lower CoF, better } \\
\text { wear resistance and superior } \\
\text { anti-adhesive property. }\end{array}$ \\
\hline
\end{tabular}


Table 2. Cont.

\begin{tabular}{|c|c|c|c|c|c|c|}
\hline \multirow{2}{*}{ References } & \multicolumn{3}{|c|}{ Deposition Parameters } & \multirow{2}{*}{$\begin{array}{l}\text { Cutting } \\
\text { Material }\end{array}$} & \multirow{2}{*}{$\begin{array}{l}\text { Experimental } \\
\text { Conditions }\end{array}$} & \multirow{2}{*}{ Results/Remarks } \\
\hline & Substrate & Coating & Technique & & & \\
\hline$[1]$ & $\begin{array}{l}\text { Tungsten } \\
\text { carbide }\end{array}$ & $\begin{array}{l}\mathrm{TiB}_{2}+ \\
\text { DLC-WS } \\
\text { multilayer } \\
\text { coating }\end{array}$ & $\begin{array}{c}\text { FCVA } \\
\text { (graphite) } \\
\text { MS (TiB } 2 \\
\mathrm{WS}_{2} \text { ) }\end{array}$ & Al-10Si & $\begin{array}{c}\text { Milling } \\
\text { (feed rate }=1880 \mathrm{~mm} / \mathrm{min}, \\
\text { tool speed }=6265 \mathrm{rpm}, \\
\mathrm{a}_{\mathrm{p}}=10 \mathrm{~mm}, \\
\left.\mathrm{~V}_{\mathrm{C}}=500 \mathrm{~m} / \mathrm{min}\right)\end{array}$ & $\begin{array}{l}\text { The two-layer } \\
\text { DLC-WS } \\
\text { reduced the tool wear, } \\
\text { enhanced the tool durability } \\
\text { and surface finish of } \\
\text { machined material. }\end{array}$ \\
\hline [65] & $\begin{array}{l}\text { YG } \\
\text { Cemented } \\
\text { carbide }\end{array}$ & $\mathrm{Ti} / \mathrm{TiC}+\mathrm{DLC}$ & $\begin{array}{l}\text { Vacuum } \\
\text { cathode } \\
\text { multi-arc } \\
\text { deposition } \\
\text { (VCAD) }\end{array}$ & $\begin{array}{l}\text { Al-22\%wt. Si } \\
\text { alloy, } \\
\text { mid-Si-Al } \\
\text { alloy and } \\
\text { Al-Cu }\end{array}$ & $\begin{array}{c}\text { Cutting (dry, } \\
\mathrm{V}_{\mathrm{C}}=180 \mathrm{~m} / \mathrm{min}, \\
\left.\mathrm{a}_{\mathrm{p}}=0.2 \mathrm{~mm}, \mathrm{f}=0.1 \mathrm{~mm} / \mathrm{r}\right)\end{array}$ & $\begin{array}{l}\text { DLC-coated insert showed } \\
\text { longer wear life for } \\
\text { machining Al-Cu and } \\
\text { mid-Si-Al alloys, no better } \\
\text { performance for high-Si-Al } \\
\text { alloy. However, the } \\
\text { diamond-coated insert has } \\
\text { an overwhelming } \\
\text { advantage for cutting these } \\
\text { aluminum alloys. }\end{array}$ \\
\hline$[64]$ & HSS & $\begin{array}{l}\mathrm{Cr} / \mathrm{CrC}+ \\
\mathrm{NH}-\mathrm{DLC} \\
\mathrm{H}-\mathrm{DLC}\end{array}$ & $\begin{array}{c}\text { MS } \\
(\mathrm{NH}-\mathrm{DLC}) \\
\mathrm{MS}+\mathrm{PECVD} \\
(\mathrm{H}-\mathrm{DLC})\end{array}$ & $\begin{array}{l}\text { Al-6Si alloy } \\
\text { (319 Al) }\end{array}$ & $\begin{array}{c}\text { drilling }\left(\mathrm{H}_{2} \mathrm{O}-\mathrm{MQL} \text { and dry, }\right. \\
\mathrm{V}_{\mathrm{C}}=50 \mathrm{~m} / \mathrm{min}, \\
\left.\mathrm{a}_{\mathrm{p}}=0.25 \mathrm{~mm} / \mathrm{rev}\right)\end{array}$ & $\begin{array}{l}\text { NH-DLC drills presented } \\
\text { better cutting performance } \\
\text { than H-DLC under } \\
\mathrm{H}_{2} \mathrm{O}-\mathrm{MQL} \text {, because of less } \\
\text { torque, thrust force and } \\
\text { smaller BUE. }\end{array}$ \\
\hline$[11]$ & $\begin{array}{l}\mathrm{Al}_{2} \mathrm{O}_{3} / \mathrm{TiCn} \\
\text { mixed } \\
\text { ceramic }\end{array}$ & $\begin{array}{c}\text { H-DLC, } \\
\text { WC/C }(2 \mu \mathrm{m})\end{array}$ & MS & $\begin{array}{l}\text { Hardened } \\
52,100 \text { steel } \\
(62 \text { HRC })\end{array}$ & $\begin{array}{c}\text { Turning }(\mathrm{dry}, \\
\mathrm{V}_{\mathrm{C}}=150 \mathrm{~m} / \mathrm{min}, \\
\left.\mathrm{a}_{\mathrm{p}}=0.12 \mathrm{~mm} / \mathrm{rev}\right)\end{array}$ & $\begin{array}{l}\text { WC/C showed a high } \mathrm{CoF} \\
\text { and lower } \mathrm{H} \text { but good wear } \\
\text { resistance and thermal } \\
\text { stability, and can stop the } \\
\text { crack propagation. }\end{array}$ \\
\hline$[70]$ & $\begin{array}{l}\text { Cemented } \\
\text { carbide }\end{array}$ & $\begin{array}{l}\mathrm{CrC} / \mathrm{C}+ \\
\mathrm{H}-\mathrm{DLC}\end{array}$ & PECVD & Al-Si alloy & $\begin{array}{c}\text { Turning }\left(\mathrm{V}_{\mathrm{C}}=450 \mathrm{~m} / \mathrm{min},\right. \\
\left.\mathrm{a}_{\mathrm{p}}=0.5 \mathrm{~mm}, \mathrm{f}=0.15 \mathrm{~mm} / \mathrm{rot}\right)\end{array}$ & $\begin{array}{l}\text { DLC-coated tools did not } \\
\text { show any superiority, } \\
\text { except for reducing the } \\
\text { feeding force. }\end{array}$ \\
\hline [96] & WC-6Co & $\begin{array}{c}\text { DLC, CVD } \\
\text { diamond }\end{array}$ & PECVD & $\begin{array}{l}\text { Al-SiC metal } \\
\text { matrix } \\
\text { composite, } \\
\text { AlZnM- } \\
\text { nCu0.5 }\end{array}$ & $\begin{array}{c}\text { Turning }(\mathrm{dry}, \\
\mathrm{V}_{\mathrm{C}}=100 \mathrm{~m} / \mathrm{min}, \\
\left.\mathrm{f}=0.1 \mathrm{~mm} / \mathrm{rev}, \mathrm{a}_{\mathrm{p}}=0.5 \mathrm{~mm}\right) \\
\text { Milling }\left(\mathrm{dry}, \mathrm{V}_{\mathrm{C}}=510 \mathrm{~m} / \mathrm{min},\right. \\
\mathrm{f}=550 \mathrm{~mm} / \mathrm{min}, \mathrm{a}_{\mathrm{p}}=6 \mathrm{~mm}, \\
\text { cutting width }=1 \mathrm{~mm})\end{array}$ & $\begin{array}{l}\text { DLC coating did not prefer } \\
\text { machining aluminum alloys } \\
\text { under dry conditions due to } \\
\text { low } \mathrm{H} \text { and bad adhesion. } \\
\text { Diamond-coated tools } \\
\text { showed improvement for } \\
\text { machining aluminum } \\
\text { alloys. }\end{array}$ \\
\hline$[71]$ & $\begin{array}{l}\text { WC-Co } \\
(6 \mathrm{wt} . \%)\end{array}$ & Diamond + DLC & $\begin{array}{l}\text { PECVD } \\
\text { (DLC) } \\
\text { hot filament } \\
\text { CVD } \\
\text { (diamond) }\end{array}$ & Al-Si alloy & $\begin{array}{c}\text { Drilling (Semi-dry with MQL, } \\
\text { depth }=18 \mathrm{~mm}, \\
\mathrm{~V}_{\mathrm{C}}=85 \mathrm{~m} / \mathrm{min} \\
\mathrm{f}=0.12 \mathrm{~mm} / \mathrm{rev})\end{array}$ & $\begin{array}{l}\text { Uncoated tools showed } \\
\text { much BUE on the cutting } \\
\text { edge and the flute. The } \\
\text { DLC/diamond-coated tools } \\
\text { showed much better } \\
\text { sticking resistance than } \\
\text { diamond-coated tools. }\end{array}$ \\
\hline
\end{tabular}

\section{Conclusions and Future Challenges}

The tool coating, as a layer between the tool substrate and the workpiece in the machining process, plays an important role to obtain excellent cutting performance, good thermal barrier effect and high-quality machined surface. DLC coating, as a kind of cuttingtool coating material, has been used in cutting various materials because of its low $\mathrm{CoF}$, high hardness and good chemical inert. However, several drawbacks in mechanical properties, such as high internal compression stress and poor adhesion to the substrate, severely limit the application of DLC coatings in machining and manufacturing. This paper provides a summary for improving the limitations of DLC coatings via various methods. Several findings are summarized as follows.

(1) The multilayer architectures in DLC coating modifications are composed of a DLC layer with high $\mathrm{sp}^{3}$ contents and other alternating layers, such as a nitride layer, a lubricant layer, a carbon-containing compound layer or a soft DLC layer with low $\mathrm{sp}^{3}$ contents. The multi-interface structures contributed to an increase in hardness 
and toughness and a decrease in internal stress by restricting the crack formation and propagation, which helps to improve the cutting performance. In particular, the period ratio and bilayer period are crucial parameters in the properties of multilayer DLC coatings.

(2) The introduction of graded transition layers can narrow the gap in the mechanical properties between the substrate and the DLC top layer, generating the redistribution of the internal stress and high adhesion to the substrate, finally increasing the wear resistance and durability of the DLC coatings. The transition layer can be a carbon-containing intermediate layer, a nitride layer, or a metal. Among the complicated layer structures such as a multilayer or graded layer structure, a multilayer architecture is not only conducive to stress relief and adhesion increase, but also crack propagation inhibition.

(3) The addition of chemical elements is an effective method for residual stress reduction and adhesion improvement and enhances the toughness by suppressing the deformation and propagation of cracks. Meanwhile, this reduces the hardness and elastic modulus of the DLC coating due to the reconfiguration of the carbon hybrid bonds $\left(\mathrm{sp}^{2}\right.$ and $\left.\mathrm{sp}^{3}\right)$. The incorporation amount of the different chemical elements generated different effects on the mechanical properties and the internal stress of the DLC coating mainly by affecting the $\mathrm{sp}^{3}$ cross-linking network.

This paper demonstrates the cutting performance of the DLC-coated tools in machining different materials. Several findings are summarized as follows:

(1) The tools with a DLC coating have noticeable superiority in machining non-ferrous metals, mainly because of their excellent anti-adhesive properties, which contribute to reducing the cutting force and friction temperature, increasing the surface smoothness of the workpiece. During the machining of titanium alloys, the DLC-coated tools presented good chemical inertness and a low coefficient of friction to enhance the tool's durability.

(2) The DLC-coated tools can be used to machine some special steel, such as highly alloyed steel, austempered ductile iron and austenitic stainless steel, due to DLC's good anti-adhesion properties and low coefficient of friction. Some modification methods, including doping with chemical elements and a multilayer architecture, can improve the DLC-coated tools' toughness and cutting performance.

(3) The DLC-coated tools are suitable to machine compound materials composed of carbon fiber-reinforced plastic (CFRP) and metals, characterized by low thermal conductivity, composition nonuniformity and abrasive characteristic; the biggest contribution of the DLC-coated tools is low $\mathrm{CoF}$, which contributed to reducing the feeding force and temperature.

Funding: The work presented here has been supported by the Science and Technology Department of Sichuan Province (2020JDRC0048).

Institutional Review Board Statement: Not applicable.

Informed Consent Statement: Not applicable.

Conflicts of Interest: The authors declare no conflict of interest.

\section{References}

1. Brzezinka, T.; Rao, J.; Paiva, J.; Kohlscheen, J.; Fox-Rabinovich, G.; Veldhuis, S.; Endrino, J. DLC and DLC-WS ${ }_{2}$ Coatings for Machining of Aluminium Alloys. Coatings 2019, 9, 192. [CrossRef]

2. Fang, F.Z.; Liu, Y.C. On minimum exit-burr in micro cutting. J. Micromech. MicroEng. 2001, 14, 984-988. [CrossRef]

3. Olvera, O.; Barrow, G. An experimental study of burr formation in square shoulder face milling. Int. J. Mach. Tools. Manuf. 1996, 36, 1005-1020. [CrossRef]

4. Suárez, A.; López De Lacalle, L.N.; Polvorosa, R.; Veiga, F.; Wretland, A. Effects of high-pressure cooling on the wear patterns on turning inserts used on alloy IN718. Mater. Manuf. Process. 2017, 32, 678-686. [CrossRef] 
5. Fernández-Lucio, P.; Villarón-Osorno, I.; Pereira Neto, O.; Ukar, E.; López De Lacalle, L.N.; Gil Del Val, A. Effects of laser-textured on rake face in turning PCD tools for Ti6Al4V. J. Mater. Res. Technol. 2021, 15, 177-188. [CrossRef]

6. Riedel, R. Handbook of Ceramic Hard Materials; Wiley-Vich Weinheim: New York, NY, USA, 2000.

7. Lacalle, N.L.D.; Mentxaka, A.L. Machine Tools for High Performance Machining; Springer Verlag London Limited: London, UK, 2008.

8. Jamari, J.; Ammarullah, M.I.; Saad, A.P.M.; Syahrom, A.; Uddin, M.; van der Heide, E.; Basri, H. The effect of bottom profile dimples on the femoral head on wear in metal-on-metal total hip arthroplasty. J. Funct. Biomater. 2021, 12, 38. [CrossRef]

9. Grigoriev, S.N.; Volosova, M.A.; Vereschaka, A.A.; Sitnikov, N.N.; Milovich, F.; Bublikov, J.I.; Fyodorov, S.V.; Seleznev, A.E. Properties of $(\mathrm{Cr}, \mathrm{Al}, \mathrm{Si}) \mathrm{N}-(\mathrm{DLC}-\mathrm{Si})$ composite coatings deposited on a cutting ceramic substrate. Ceram. Int. 2020, 46, 18241-18255. [CrossRef]

10. Huang, L.; Yuan, J.; Li, C.; Hong, D. Microstructure, tribological and cutting performance of Ti-DLC/ $\alpha-C: H$ multilayer film on cemented carbide. Surf. Coat. Technol. 2018, 353, 163-170. [CrossRef]

11. Kumar, C.S.; Majumder, H.; Khan, A.; Patel, S.K. Applicability of DLC and WC/C low friction coatings on $\mathrm{Al}_{2} \mathrm{O}_{3} / \mathrm{TiCN} \mathrm{mixed}^{2}$ ceramic cutting tools for dry machining of hardened 52100 steel. Ceram. Int. 2020, 46, 11889-11897. [CrossRef]

12. Fernández-Abia, A.I.; Barreiro, J.; Fernández-Larrinoa, J.; Lacalle, L.N.L.D.; Fernández-Valdivielso, A.; Pereira, O.M. Behaviour of PVD Coatings in the Turning of Austenitic Stainless Steels. Procedia Eng. 2013, 63, 133-141. [CrossRef]

13. Rodríguez-Barrero, S.; Fernández-Larrinoa, J.; Azkona, I.; López De Lacalle, L.N.; Polvorosa, R. Enhanced Performance of Nanostructured Coatings for Drilling by Droplet Elimination. Mater. Manuf. Process. 2016, 31, 593-602. [CrossRef]

14. de lacalle, L.N.L.; Pérez, J.; Llorente, J.I.; Sánchez, J.A. Advanced cutting conditions for the milling of aeronautical alloys. J. Mater. Process. Technol. 2000, 100,1-11. [CrossRef]

15. Fernández-Abia, A.I.; Barreiro, J.; López De Lacalle, L.N.; Martínez-Pellitero, S. Behavior of austenitic stainless steels at high speed turning using specific force coefficients. Int. J. Adv. Manuf. Technol. 2012, 62, 505-515. [CrossRef]

16. Polvorosa, R.; de Lacalle, L.N.L.; Egea, A.J.S.; Fernandez, A.; Esparta, M.; Zamakona, I. Cutting edge control by monitoring the tapping torque of new and resharpened tapping tools in Inconel 718. Int. J. Adv. Manuf. Technol. 2020, 106, 3799-3808. [CrossRef]

17. Kumar, C.S.; Patel, S.K. Effect of chip sliding velocity and temperature on the wear behaviour of PVD AlCrN and AlTiN coated mixed alumina cutting tools during turning of hardened steel. Surf. Coat. Technol. 2018, 334, 509-525. [CrossRef]

18. Bhowmick, S.; Banerji, A.; Alpas, A.T. Tribological behavior of Al-6.5\%, $-12 \%,-18.5 \%$ Si alloys during machining using CVD diamond and DLC coated tools. Surf. Coat. Technol. 2015, 284, 353-364. [CrossRef]

19. Pérez-Ruiz, J.D.; de Lacalle, L.N.L.; Urbikain, G.; Pereira, O.; Martínez, S.; Bris, J. On the relationship between cutting forces and anisotropy features in the milling of LPBF Inconel 718 for near net shape parts. Int. J. Mach. Tools Manuf. 2021, 170, 103801. [CrossRef]

20. Pérez-Ruiz, J.D.; Marin, F.; Martínez, S.; Lamikiz, A.; Urbikain, G.; López De Lacalle, L.N. Stiffening near-net-shape functional parts of Inconel 718 LPBF considering material anisotropy and subsequent machining issues. Mech. Syst. Signal Process. 2022, 168, 108675. [CrossRef]

21. Basso, I.; Voigt, R.; Rodrigues, A.R.; Marin, F.; de Souza, A.F.; de Lacalle, L.N.L. Influences of the workpiece material and the tool-surface engagement (TSE) on surface finishing when ball-end milling. J. Manuf. Process. 2022, 75, 219-231. [CrossRef]

22. Khanna, N.; Shah, P.; de Lacalle, L.N.L.; Rodríguez, A.; Pereira, O. In pursuit of sustainable cutting fluid strategy for machining Ti-6Al-4V using life cycle analysis. Sustain. Mater. Technol. 2021, 29, 301. [CrossRef]

23. Rodríguez, A.; Calleja, A.; de Lacalle, L.N.L.; Pereira, O.; Rubio-Mateos, A.; Rodríguez, G. Drilling of CFRP-Ti6Al4V stacks using $\mathrm{CO}_{2}$-cryogenic cooling. J. Manuf. Process. 2021, 64, 58-66. [CrossRef]

24. Amigo, F.J.; Urbikain, G.; Pereira, O.; Fernández-Lucio, P.; Fernández-Valdivielso, A.; de Lacalle, L.N.L. Combination of high feed turning with cryogenic cooling on Haynes 263 and Inconel 718 superalloys. J. Manuf. Process. 2020, 58, 208-222. [CrossRef]

25. Pereira, O.; Celaya, A.; Urbikaín, G.; Rodríguez, A.; Fernández-Valdivielso, A.; de Lacalle, L.N.L. CO 2 cryogenic milling of Inconel 718: Cutting forces and tool wear. J. Mater. Res. Technol. 2020, 9, 8459-8468. [CrossRef]

26. Klocke, F.; Gerschwiler, K.; Schiffler, M.; Morstein, M.; Dessarzin, P.; Lung, D.; Frank, H. Adapted DLC coatings for increasing tapping performance in TiAl6V4. Materialwiss. Werkst. 2013, 44, 710-715. [CrossRef]

27. Sedlaček, M.; Podgornik, B.; Vižintin, J. Tribological properties of DLC coatings and comparison with test results: Development of a database. Mater. Charact. 2008, 59, 151-161. [CrossRef]

28. Sheeja, D.; Tay, B.K.; Lau, S.P.; Shi, X. Tribological properties and adhesive strength of DLC coatings prepared under different substrate bias voltages. Wear 2001, 249, 433-439. [CrossRef]

29. Robertson, J. Diamond-like amorphous carbon. Mater. Sci. Eng. R. 2002, 37, 129-281. [CrossRef]

30. Chen, K.; Lin, J. The study of adhesion and nanomechanical properties of DLC films deposited on tool steels. Thin Solid Films 2009, 517, 4916-4920. [CrossRef]

31. Aizawa, T.; Masaki, E.; Sugita, Y. Complete ashing of used DLC coating for reuse of the end-milling tools. Manuf. Lett. 2014, 2, 1-3. [CrossRef]

32. Baowan, P.; Saikaew, C.; Wisitsoraat, A. Influence of helix angle on tool performances of TiAlN- and DLC-coated carbide end mills for dry side milling of stainless steel. Int. J. Adv. Manuf. Technol. 2017, 90, 3085-3097. [CrossRef]

33. Silva, W.M.; Jesus, L.M.; Carneiro, J.R.; Souza, P.S.; Martins, P.S.; Trava-Airoldi, V.J. Performance of carbide tools coated with DLC in the drilling of SAE 323 aluminum alloy. Surf. Coat. Technol. 2015, 284, 404-409. [CrossRef] 
34. Nemati, N.; Penkov, O.V.; Kim, D. Superior surface protection governed by optimized interface characteristics in WC/DLC multilayer coating. Surf. Coat. Technol. 2020, 385, 125446. [CrossRef]

35. Misra, A.; Hirth, J.P.; Hoagland, R.G. Length-scale-dependent deformation mechanisms in incoherent metallic multilayered composites. Acta Mater. 2005, 53, 4817-4824. [CrossRef]

36. Kot, M.; Major, A.; Lackner, J. The tribological phenomena of a new type of TiN/a-C:H multilayer coatings. Mater. Des. 2013, 51, 280-286. [CrossRef]

37. Liu, L.; Wu, Z.; An, X.; Shao, T.; Xiao, S.; Cui, S.; Lin, H.; Fu, R.K.Y.; Tian, X.; Chu, P.K.; et al. Improved interfacial adhesion between TiAlN/DLC multi-layered coatings by controlling the morphology via bias. Surf. Coat. Technol. 2017, 331, 15-20. [CrossRef]

38. Yang, F.; Lu, Y.; Zhang, R.; Zhang, X.; Zheng, X. Microstructure and tribological properties of WSX/a-C multilayer films with various layer thickness ratios in different environments. Surf. Coat. Technol. 2017, 309, 187-194. [CrossRef]

39. Wei, J.; Li, H.; Liu, L.; Guo, P.; Ke, P.; Wang, A. Enhanced tribological and corrosion properties of multilayer ta-C films via alternating sp ${ }^{3}$ content. Surf. Coat. Technol. 2019, 374, 317-326. [CrossRef]

40. Lin, Y.; Zhou, Z.; Li, K.Y. Improved wear resistance at high contact stresses of hydrogen-free diamond-like carbon coatings by carbon/carbon multilayer architecture. Appl. Surf. Sci. 2019, 477, 137-146. [CrossRef]

41. Hofmann, D.; Kunkel, S.; Bewilogua, K.; Wittorf, R. From DLC to Si-DLC based layer systems with optimized properties for tribological applications. Surf. Coat. Technol. 2013, 215, 357-363. [CrossRef]

42. Lubwama, M.; Corcoran, B.; Sayers, K.; Kirabira, J.B.; Sebbit, A.; McDonnell, K.A.; Dowling, D. Adhesion and composite micro-hardness of DLC and Si-DLC films deposited on nitrile rubber. Surf. Coat. Technol. 2012, 206, 4881-4886. [CrossRef]

43. Qiang, L.; Bai, C.; Gong, Z.; Liang, A.; Zhang, J. Microstructure, adhesion and tribological behaviors of Si interlayer/Si doping diamond-like carbon film developed on nitrile butadiene rubber. Diam. Relat. Mater. 2019, 92, 208-218. [CrossRef]

44. Henderer, W.; Xu, F. Hybrid TiSiN, CrC/C PVD coatings applied to cutting tools. Surf. Coat. Technol. 2013, 215, 381-385. [CrossRef]

45. Fernández Landeta, J.; Fernández Valdivielso, A.; López de Lacalle, L.N.; Girot, F.; Pérez Pérez, J.M. Wear of Form Taps in Threading of Steel Cold Forged Parts. J. Manuf. Sci. E-T ASME 2015, 137, 031002. [CrossRef]

46. Cheng, L.-C.; Ho, W.-Y. Characteristics of CrAlSiN + DLC double layered coating deposited by cathodic arc evaporation process. In Proceedings of the 2018 6th International Conference on Mechanical, Automotive and Materials Engineering, Hong Kong, China, 10-12 August 2018; pp. 14-17.

47. Gayathri, S.; Krishnan, R.; Ravindran, T.R.; Sundari, S.T.; Dash, S.; Tyagi, A.K.; Raj, B.; Sridharan, M. Spectroscopic studies on DLC/TM (Cr, Ag, Ti, Ni) multilayers. Mater. Res. Bull. 2012, 47, 843-849. [CrossRef]

48. Wei, C.; Wang, Y.; Tai, F. The role of metal interlayer on thermal stress, film structure, wettability and hydrogen content for diamond like carbon films on different substrate. Diam. Relat. Mater. 2009, 18, 407-412. [CrossRef]

49. Wei, C.; Yen, J. Effect of film thickness and interlayer on the adhesion strength of diamond like carbon films on different substrates. Diam. Relat. Mater. 2007, 16, 1325-1330. [CrossRef]

50. Shahsavari, F.; Ehteshamzadeh, M.; Amin, M.H.; Barlow, A.J. A comparative study of surface morphology, mechanical and tribological properties of DLC films deposited on Cr and Ni nanolayers. Ceram. Int. 2020, 46, 5077-5085. [CrossRef]

51. Duminica, F.D.; Belchi, R.; Libralesso, L.; Mercier, D. Investigation of Cr(N)/DLC multilayer coatings elaborated by PVD for high wear resistance and low friction applications. Surf. Coat. Technol. 2018, 337, 396-403. [CrossRef]

52. Sui, X.; Liu, J.; Zhang, S.; Yang, J.; Hao, J. Microstructure, mechanical and tribological characterization of CrN/DLC/Cr-DLC multilayer coating with improved adhesive wear resistance. Appl. Surf. Sci. 2018, 439, 24-32. [CrossRef]

53. Singh, V.; Jiang, J.C.; Meletis, E.I. Cr-diamondlike carbon nanocomposite films: Synthesis, characterization and properties. Thin Solid Films 2005, 489, 150-158. [CrossRef]

54. Jo, Y.J.; Zhang, T.F.; Son, M.J.; Kim, K.H. Synthesis and electrochemical properties of Ti-doped DLC films by a hybrid PVD/PECVD process. Appl. Surf. Sci. 2018, 433, 1184-1191. [CrossRef]

55. Zou, C.W.; Wang, H.J.; Feng, L.; Xue, S.W. Effects of Cr concentrations on the microstructure, hardness, and temperaturedependent tribological properties of Cr-DLC coatings. Appl. Surf. Sci. 2013, 286, 137-141. [CrossRef]

56. Santiago, J.A.; Fernández-Martínez, I.; Sánchez-López, J.C.; Rojas, T.C.; Wennberg, A.; Bellido-González, V.; Molina-Aldareguia, J.M.; Monclús, M.A.; González-Arrabal, R. Tribomechanical properties of hard Cr-doped DLC coatings deposited by low-frequency HiPIMS. Surf. Coat. Technol. 2020, 382, 124899. [CrossRef]

57. Wang, A.; Lee, K.; Ahn, J.; Han, J.H. Structure and mechanical properties of W incorporated diamond-like carbon films prepared by a hybrid ion beam deposition technique. Carbon 2006, 44, 1826-1832. [CrossRef]

58. Daniel, R.; Martinschitz, K.J.; Keckes, J.; Mitterer, C. The origin of stresses in magnetron-sputtered thin films with zone T structures. Acta Mater. 2010, 58, 2621-2633. [CrossRef]

59. Robertson, J. Deposition mechanisms for promoting $\mathrm{sp}^{3}$ bonding in diamond-like carbon. Diam. Relat. Mater. 1993, 5-7, 984-989. [CrossRef]

60. Manninen, N.K.; Ribeiro, F.; Escudeiro, A.; Polcar, T.; Carvalho, S.; Cavaleiro, A. Influence of Ag content on mechanical and tribological behavior of DLC coatings. Surf. Coat. Technol. 2013, 232, 440-446. [CrossRef]

61. Zhou, S.; Wang, L.; Wang, S.C.; Xue, Q. Comparative study of simplex doped nc-WC/a-C and duplex doped nc-WC/a-C(Al) nanocomposite coatings. Appl. Surf. Sci. 2011, 257, 6971-6979. [CrossRef] 
62. Ferrari, A.C.; Rodil, S.E.; Robertson, J.; Milne, W.I. Is stress necessary to stabilise $\mathrm{sp}^{3}$ bonding in diamond-like carbon? Diam. Relat. Mater. 2002, 11, 994-999. [CrossRef]

63. Wu, Y.; Chen, J.; Li, H.; Ji, L.; Ye, Y.; Zhou, H. Preparation and properties of Ag/DLC nanocomposite films fabricated by unbalanced magnetron sputtering. Appl. Surf. Sci. 2013, 284, 165-170. [CrossRef]

64. Bhowmick, S.; Alpas, A.T. Minimum quantity lubrication drilling of aluminium-silicon alloys in water using diamond-like carbon coated drills. Int. J. Mach. Tools Manuf. 2008, 48, 1429-1443. [CrossRef]

65. Dai, M.; Zhou, K.; Yuan, Z.; Ding, Q.; Fu, Z. The cutting performance of diamond and DLC-coated cutting tools. Diam. Relat. Mater. 2000, 9, 1753-1757. [CrossRef]

66. Lahres, M.; Müller-Hummel, P.; Doerfel, O. Applicability of different hard coatings in dry milling aluminium alloys. Surf. Coat Technol. 1997, 91, 116-121. [CrossRef]

67. Enke, K. Dry machining and increase of endurance of machine parts with improved doped DLC coatings on steel, ceramics and aluminium. Surf. Coat. Technol. 1999, 116-119, 488-491. [CrossRef]

68. Dosbaeva, J.; Fox-Rabinovich, G.; Dasch, J.; Veldhuis, S. Enhancement of Wet- and MQL-Based Machining of Automotive Alloys Using Cutting Tools with DLC/Polymer Surface Treatments. J. Mater. Eng. Perform. 2008, 17, 346-351. [CrossRef]

69. Fukui, H.; Okida, J.; Omori, N.; Moriguchi, H.; Tsuda, K. Cutting performance of DLC coated tools in dry machining aluminum alloys. Surf. Coat. Technol. 2004, 187, 70-76. [CrossRef]

70. Santos, G.R.D.; da Costa, D.D.; Amorim, F.L.; Torres, R.D. Characterization of DLC thin film and evaluation of machining forces using coated inserts in turning of Al-Si alloys. Surf. Coat. Technol. 2007, 202, 1029-1033. [CrossRef]

71. Hanyu, H.; Kamiya, S.; Murakami, Y.; Kondoh, Y. The improvement of cutting performance in semi-dry condition by the combination of DLC coating and CVD smooth surface diamond coating. Surf. Coat. Technol. 2005, 200, 1137-1141. [CrossRef]

72. Ucun, I.; Aslantas, K.; Bedir, F. The performance of DLC-coated and uncoated ultra-fine carbide tools in micromilling of Inconel 718. Precis. Eng. 2015, 41, 135-144. [CrossRef]

73. Ammarullah, M.I.; Afif, I.Y.; Maula, M.I.; Winarni, T.I.; Tauviqirrahman, M.; Akbar, I.; Basri, H.; van der Heide, E.; Jamari, J. Tresca stress simulation of metal-on-metal total hip arthroplasty during normal walking activity. Materials 2021, 14, 7554. [CrossRef]

74. Dolinšek, S. Work-hardening in the drilling of austenitic stainless steels. J. Mater. Process. Technol. 2003, 133, 63-70. [CrossRef]

75. Filiz, S.; Conley, C.M.; Wasserman, M.B.; Ozdoganlar, O.B. An experimental investigation of micro-machinability of copper 101 using tungsten carbide micro-endmills. Int. J. Mach. Tools Manuf. 2007, 47, 1088-1100. [CrossRef]

76. Ziberov, M.; de Oliveira, D.; da Silva, M.B.; Hung, W.N.P. Wear of TiAlN and DLC coated microtools in micromilling of Ti-6Al-4V alloy. J. Manuf. Process. 2020, 56, 337-349. [CrossRef]

77. Lin, S.Y.; Yu, S.H.; Wu, M.L. Effect of Different Coating Materials on Cutting Performance in High-Speed Machining of Mold Steels. Key Eng. Mater. 2007, 364-366, 1026-1031. [CrossRef]

78. Badiger, P.V.; Desai, V.; Ramesh, M.R. Performance of DLC coated tool during machining of MDN431 alloyed steel. Mater. Today Proc. 2018, 5, 17360-17370. [CrossRef]

79. Elosegui, I.; Alonso, U.; de Lacalle, L.N.L. PVD coatings for thread tapping of austempered ductile iron. Int. J. Adv. Manuf. Technol. 2017, 91, 2663-2672. [CrossRef]

80. Fox-Rabinovich, G.; Dasch, J.M.; Wagg, T.; Yamamoto, K.; Veldhuis, S.; Dosbaeva, G.K.; Tauhiduzzaman, M. Cutting performance of different coatings during minimum quantity lubrication drilling of aluminum silicon B319 cast alloy. Surf. Coat. Technol. 2011, 205, 4107-4116. [CrossRef]

81. D'Orazio, A.; el Mehtedi, M.; Forcellese, A.; Nardinocchi, A.; Simoncini, M. Tool wear and hole quality in drilling of CFRP/AA7075 stacks with DLC and nanocomposite TiAlN coated tools. J. Manuf. Process. 2017, 30, 582-592. [CrossRef]

82. Donnet, C.; Erdemir, A. Tribology of Diamond-Like Carbon Films; Springer Science + Business Media, LLC.: New York, NY, USA, 2008.

83. Luo, B.; Li, Y.; Zhang, K.; Cheng, H.; Liu, S. A novel prediction model for thrust force and torque in drilling interface region of CFRP/Ti stacks. Int. J. Adv. Manuf. Technol. 2015, 81, 1497-1508. [CrossRef]

84. Kuo, C.; Li, Z.; Wang, C. Multi-objective optimization in vibration-assisted drilling of CFRP/Al stacks. Compos. Struct. 2017, 173, 196-209. [CrossRef]

85. Zitoune, R.; Krishnaraj, V.; Almabouacif, B.S.; Collombet, F.; Sima, M.; Jolin, A. Influence of machining parameters and new nano-coated tool on drilling performance of CFRP/Aluminium sandwich. Compos. Part B Eng. 2012, 43, 1480-1488. [CrossRef]

86. Gaugel, S.; Sripathy, P.; Haeger, A.; Meinhard, D.; Bernthaler, T.; Lissek, F.; Kaufeld, M.; Knoblauch, V.; Schneider, G. A comparative study on tool wear and laminate damage in drilling of carbon-fiber reinforced polymers (CFRP). Compos. Struct. 2016, 155, 173-183. [CrossRef]

87. Marques, A.T.; Durão, L.M.; Magalhães, A.G.; Silva, J.F.; Tavares, J.M.R.S. Delamination analysis of carbon fibre reinforced laminates: Evaluation of a special step drill. Compos. Sci. Technol. 2009, 69, 2376-2382. [CrossRef]

88. Poutord, A.; Rossi, F.; Poulachon, G.; M'Saoubi, R.; Abrivard, G. Local Approach of Wear in Drilling Ti6Al4V/CFRP for Stack Modelling. Procedia CIRP 2013, 8, 316-321. [CrossRef]

89. Wang, X.; Kwon, P.Y.; Sturtevant, C.; Kim, D.D.; Lantrip, J. Comparative tool wear study based on drilling experiments on CFRp/Ti stack and its individual layers. Wear 2014, 317, 265-276. [CrossRef]

90. Wei, Y.; An, Q.; Ming, W.; Chen, M. Effect of drilling parameters and tool geometry on drilling performance in drilling carbon fiber-reinforced plastic/titanium alloy stacks. Adv. Mech. Eng. 2016, 8, 2071836116. [CrossRef] 
91. Xu, J.; Mansori, M.E. Experimental Studies on the Cutting Characteristics of Hybrid CFRP/Ti Stacks. Procedia Manuf. 2016, 5, 270-281. [CrossRef]

92. Xu, J.; El Mansori, M. Wear characteristics of polycrystalline diamond tools in orthogonal cutting of CFRP/Ti stacks. Wear 2017, 376-377, 91-106. [CrossRef]

93. Zhang, L.; Liu, Z.; Tian, W.; Liao, W. Experimental studies on the performance of different structure tools in drilling CFRP/Al alloy stacks. Int. J. Adv. Manuf. Technol. 2015, 81, 241-251. [CrossRef]

94. Zitoune, R.; Krishnaraj, V.; Collombet, F.; le Roux, S. Experimental and numerical analysis on drilling of carbon fibre reinforced plastic and aluminium stacks. Compos. Struct. 2016, 146, 148-158. [CrossRef]

95. Zhang, D.; Shen, B.; Sun, F. Study on tribological behavior and cutting performance of CVD diamond and DLC films on Co-cemented tungsten carbide substrates. Appl. Surf. Sci. 2010, 256, 2479-2489. [CrossRef]

96. Vandevelde, T.C.S.; Vandierendonck, K.; van Stappen, M.; Mong, W.D.; Perremans, P. Cutting applications of DLC, hard carbon and diamond films. Surf. Coat. Technol. 1999, 113, 80-85. [CrossRef] 